\title{
The human ortholog of archaeal Pus10 produces pseudouridine 54 in select tRNAs where its recognition sequence contains a modified residue
}

\author{
MANISHA DEOGHARIA, ${ }^{1}$ SHAONI MUKHOPADHYAY, ARCHI JOARDAR ${ }^{2}$ and RAMESH GUPTA \\ Department of Biochemistry and Molecular Biology, Southern Illinois University, Carbondale, Illinois 62901-4413, USA
}

\begin{abstract}
The nearly conserved U54 of tRNA is mostly converted to a version of ribothymidine (T) in Bacteria and eukaryotes and to a version of pseudouridine $(\Psi)$ in Archaea. Conserved U55 is nearly always modified to $\Psi 55$ in all organisms. Orthologs of TrmA and TruB that produce T54 and $\Psi 55$, respectively, in Bacteria and eukaryotes are absent in Archaea. Pus10 produces both $\Psi 54$ and $\Psi 55$ in Archaea. Pus 10 orthologs are found in nearly all sequenced archaeal and most eukaryal genomes, but not in yeast and bacteria. This coincides with the presence of $\Psi 54$ in most archaeal tRNAs and some animal tRNAs, but its absence from yeast and bacteria. Moreover, $\Psi 54$ is found in several tRNAs that function as primers for retroviral DNA synthesis. Previously, no eukaryotic tRNA $\Psi 54$ synthase had been identified. We show here that human Pus10 can produce $\Psi 54$ in select tRNAs, including tRNA ${ }^{\text {Lys3 }}$, the primer for HIV reverse transcriptase. This synthase activity of Pus 10 is restricted to the cytoplasm and is distinct from nuclear Pus10, which is known to be involved in apoptosis. The sequence GUUCAm ${ }^{1}$ AAUC ( $m^{1} A$ is 1-methyladenosine) at position 53-61 of tRNA along with a stable acceptor stem results in maximum $\Psi 54$ synthase activity. This recognition sequence is unique for a $\Psi$ synthase in that it contains another modification. In addition to $\Psi 54$, SF9 cells-derived recombinant human Pus10 can also generate $\Psi 55$, even in tRNAs that do not contain the Y54 synthase recognition sequence. This activity may be redundant with that of TruB.
\end{abstract}

Keywords: tRNA modification; pseudouridine synthase; TruB; retroviral primer; mRNA modification; 1-methyladenosine

\section{INTRODUCTION}

A typical tRNA contains a 17-base stem-loop structure called the "common arm" or "T $\Psi C$ arm" at position 4965. Most tRNAs contain a consensus GUUCRANYC sequence at position 53-61 in this arm; the UUCRANY part of which forms the loop (Gupta 1985; Jühling et al. 2009). TYC includes T (ribothymidine or 5-methyluridine) and $\Psi$ (pseudouridine) modifications of the two U's at positions 54 and 55 in the consensus sequence, followed by a $C$ at position 56. The U54 is commonly modified to T54 in most Bacteria and Eukarya, but rarely in Archaea. The U55 is converted to $\Psi 55$ in nearly all tRNAs (Jühling et al. 2009). Most archaeal tRNAs, especially those of Euryarchaeota, contain $\Psi$ or $\mathrm{m}^{1} \Psi$ (1-methylpseudouridine) at position 54 instead of T (Gupta 1984, 1985, 1986; Jühling et al. 2009; Blaby et al. 2011; Chatterjee et al. 2012).

\footnotetext{
${ }^{1}$ Present address: Department of Anatomy and Structural Biology Albert Einstein College of Medicine, Bronx, New York 10461, USA

${ }^{2}$ Present address: Icagen, Oro Valley, Arizona 85755, USA

Corresponding author: rgupta@siumed.edu

Article is online at http://www.rnajournal.org/cgi/doi/10.1261/rna. 068114.118.
}

Bacterial tRNA methyltransferase, TrmA and tRNA $\Psi$ synthase, TruB (and their eukaryal orthologs Trm2 and Pus4) produce T54 and $\Psi 55$, respectively ( $\mathrm{Ny}$ and Björk 1980; Nurse et al. 1995; Becker et al. 1997; Nordlund et al. 2000). Archaea lack orthologs of these enzymes. Archaea and Eukarya contain Cbf5, a box H/ACA guide RNA-dependent $\Psi$ synthase, which structurally belongs to the TruB family of $\Psi$ synthases (Koonin 1996; Watanabe and Gray 2000; Mueller and Ferre-D'Amare 2009). In vitro, archaeal Cbf5 can also produce $\Psi 55$ in tRNA and $\Psi$ at some positions in rRNA in a guide RNA-independent manner (Roovers et al. 2006; Gurha et al. 2007; Muller et al. 2007, 2008; Kamalampeta and Kothe 2012), but this activity of Cbf5 has only been shown in vivo for rRNA (Fujikane et al. 2018). On the other hand, archaeal Pus10 (PsuX), a $\Psi$ synthase distinct from the TruB family (Watanabe and Gray 2000; Mueller and Ferre-D'Amare 2009; Rintala-Dempsey and Kothe 2017), can produce both $\Psi 54$ and $\Psi 55$ in

\footnotetext{
(C) 2019 Deogharia et al. This article is distributed exclusively by the RNA Society for the first 12 months after the full-issue publication date (see http://rnajournal.cshlp.org/site/misc/terms.xhtml). After 12 months, it is available under a Creative Commons License (Attribution-NonCommercial 4.0 International), as described at http:// creativecommons.org/licenses/by-nc/4.0/.
} 
tRNA, both in vitro and in vivo (Gurha and Gupta 2008; Joardar et al. 2013). Instead of a bacterial TrmA ortholog, an ortholog of bacterial RumA, an rRNA-methyltransferase, produces T54 in the tRNAs of some Archaea (Urbonavicius et al. 2008). Pus 10 produces only $\Psi 55$ in these T54-containing archaeal tRNAs (Roovers et al. 2006; Gurha and Gupta 2008; Joardar et al. 2013).

Orthologs of archaeal Pus 10 are present in most eukaryotes, but not in bacteria and dikaryon fungi including yeast (Watanabe and Gray 2000; Roovers et al. 2006; Gurha and Gupta 2008; Fitzek et al. 2018). This coincides with the presence of $\Psi 54$ in certain tRNAs of animals, and its absence from the tRNAs of bacteria and yeast (Jühling et al. 2009). Certain isoacceptors of mammalian tRNAs for Gln, Trp, Pro, Thr, and Arg and of chicken tRNAs for Pro and Trp contain $\Psi$, instead of $T$, at position 54 (Harada et al. 1975, 1979, 1989; Fournier et al. 1978; Harada and Nishimura 1980; Yang et al. 1983; Keith 1984; Kuchino et al. 1987; Harada 1989; Jühling et al. 2009).

Several $\Psi 54$-containing tRNAs are reported to associate with retroviruses because these function as primers in retroviral DNA synthesis or were isolated from leukemia cells. These are tRNAs for Trp, Pro, Arg, Thr, and Gln (Harada et al. 1975, 1979; Harada and Nishimura 1980; Hu and Dahlberg 1983; Colicelli and Goff 1986; Harada 1989; Marquet et al. 1995; Mak and Kleiman 1997). The amount of a particular $\Psi 54$-containing tRNA ${ }^{\text {Gln }}$ increases in Moloney murine leukemia virus-infected mouse cells and in Ehrlich ascites cells (Kuchino et al. 1987). This tRNA has a UmUG (Um is 2'-O-methyluridine) anticodon, which is suggested to read-through the UAG stop codon between the gag and pol genes to produce a viral protease. Similarly, mammalian tRNA ${ }^{\text {Lys2 }}$, which normally contains $\operatorname{Tm}\left(2^{\prime}-O-\right.$ methylribothymidine) at position 54, increases in SV40transformed mouse fibroblast (BALB/3T3) cells and other dividing and proliferating tissues (Raba et al. 1979). This tRNA shows a mixture of $U, T, T m$, and $\Psi$ at position 54 in a 3:30:60:10 ratio (Raba et al. 1979). The tRNA $\Psi 54$ synthase activity has also been identified in Xenopus laevis oocytes (Nishikura and De Robertis 1981; Grosjean et al. 1996).

So far, no protein responsible for the tRNA $\Psi 54$ synthase activity has been identified in eukaryotes. Previously done multiple sequence alignments (McCleverty et al. 2007; Fitzek et al. 2018) have shown that though eukaryotic Pus10 proteins are much larger than archaeal Pus10, they do contain the full set of five residues (catalytic Asp, an Arg/Lys, a Tyr/Phe, a hydrophobic residue and a Leu) that are conserved within the active sites of all $\Psi$ synthases (McCleverty et al. 2007; Mueller and Ferre-D'Amare 2009). In addition, both archaeal and eukaryotic Pus10 share two more conserved residues with several $\Psi$ synthases: an Arg, two residues $\mathrm{N}$-terminal, and an Asp, two residues $\mathrm{C}$-terminal to the catalytic Asp, which have been shown to be important for the activity of archaeal Pus10 (Joardar et al.
2013; Kamalampeta et al. 2013; Fitzek et al. 2018). The crystal structure of human Pus10 suggests that it is a bona fide $\Psi$ synthase (McCleverty et al. 2007). Structural alignment of human Pus10 and Methanocaldococcus jannaschii Pus 10 showed nearly superimposable catalytic domains (Joardar et al. 2013). Although, the $\Psi$ synthase activity of human Pus10 has not been demonstrated, it has been shown that the version of this protein located in the nucleus is involved in TRAIL-induced apoptosis (Aza-Blanc et al. 2003; Jana et al. 2017).

Here we show that human Pus 10 can produce $\Psi 54$ in select tRNAs, including tRNA ${ }^{\text {Lys3 }}$, the primer for HIV DNA synthesis. It shows maximum activity when the TYC arm consensus sequence is restricted to GUUCAm ${ }^{1} A A U C$ $\left(\mathrm{m}^{1} \mathrm{~A}\right.$ is 1 -methyladenosine and the underlined $\mathrm{U}$ is modified to 454 ). U55 and A58 are essential in this sequence. So far, the involvement of another modification in $\Psi$ formation has not been reported. Destabilization of the acceptor stem of the tRNA by non-Watson-Crick pairs considerably reduces this activity. Recombinant human Pus10 can also selectively produce $\Psi 54$ in certain tRNAs and tRNA-fragments. In addition, recombinant Pus 10 shows tRNA $\Psi 55$ synthase activity in tRNAs that normally contain 454 as well as those that do not contain $\Psi 54$. This $\Psi 55$ activity of Pus10 may be redundant with that of TruB inside the cell. However, the tRNA $\Psi 54$ synthase activity of Pus 10 is unique.

\section{RESULTS}

\section{$\Psi$ is present at position 54 in certain mammalian tRNAs}

The presence of $\Psi 54$ in mammalian tRNAs was mostly determined by sequencing the individually isolated tRNA species. Mammalian genomes contain multiple tRNA genes that are transcribed to produce a tRNA pool of several isoacceptors and isodecoders for each amino acid. Therefore, we determined whether a significant population of tRNAs for certain amino acids in HeLa and mouse liver cells contained $\Psi 54$. We used primer extension after 1-cyclohexyl-3-(2-morpholinoethyl) carbodiimide methop-toluenesulfonate (CMCT) treatment of tRNA-enriched total RNA to determine the presence or absence of $\Psi 54$ in the human and mouse tRNA pools of some amino acids (Fig. 1A,B). As expected, all tRNAs contain $\Psi$ at position 55. $\Psi$ is also present at position 54 in HeLa tRNAs for Gln, Trp, and Thr, but not Phe and Asp, and mouse tRNAs for Gln and Arg, but not Phe. The presence of $\Psi 54$, if any, in Lys tRNAs could not be determined because Tm (2'-O-methylribothymidine) commonly present at position 54 in these tRNAs inhibits primer extension for unknown reasons. This has also been observed by others (Muthuswami et al. 2002). Most mammalian tRNAs contain $m^{1} A$ at position 58 , which strongly inhibits primer 
A
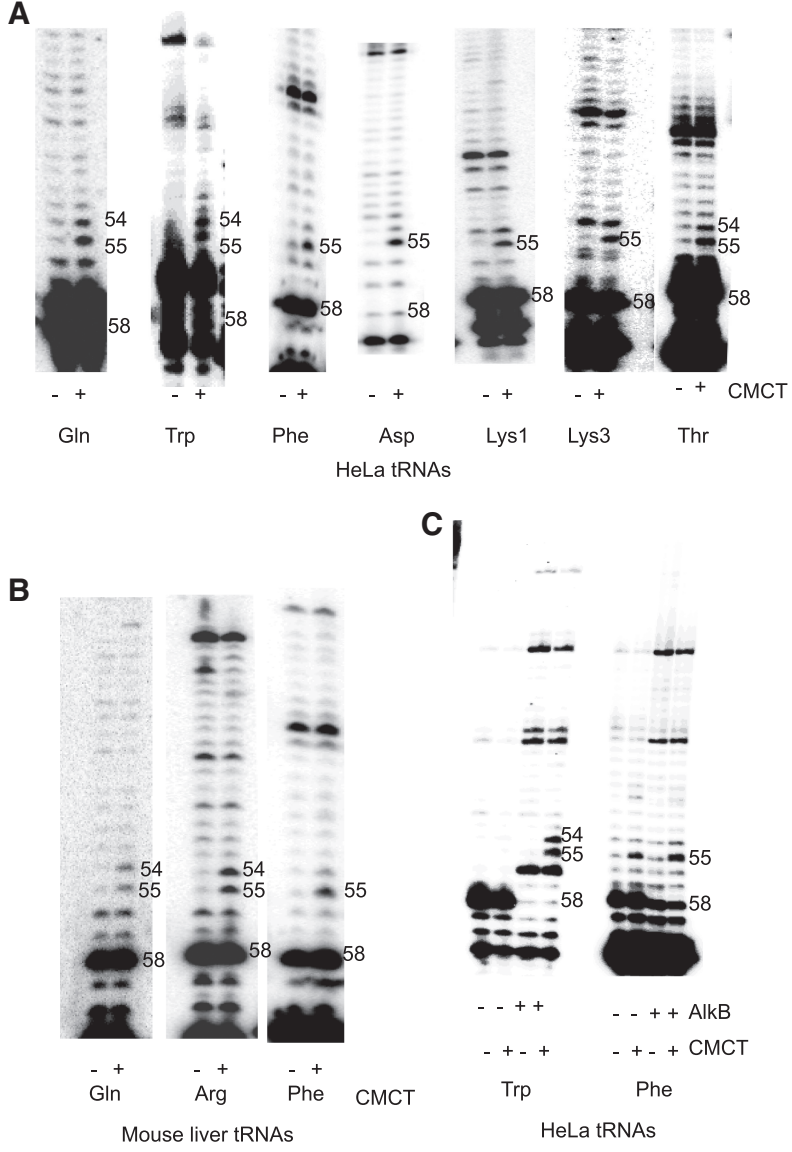

c)

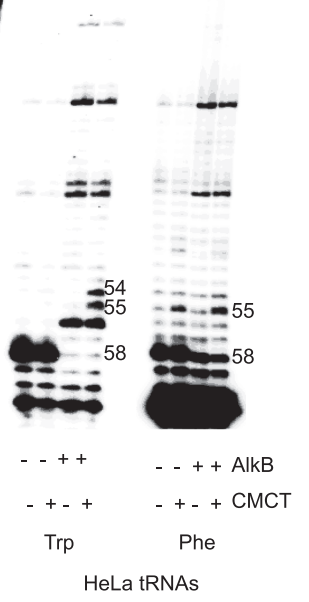

FIGURE 1. CMCT-primer extension analyses to determine the presence of $\Psi 54$ in selected mammalian tRNAs. (A) HeLa cell and $(B)$ mouse liver tRNA-enriched total RNAs were either not treated (-) or treated with $\mathrm{CMCT}(+)$ for $20 \mathrm{~min}$, followed by alkali treatment before primer extension reactions. The sequence of each primer (Supplemental Table S1) for the tRNA of a particular amino acid corresponds to the 15 bases at position 62-76 of one isoacceptor for that amino acid (indicated below each panel). A dark band in the CMCT lane but not in the untreated lane indicates a $\Psi$. Dark bands in both lanes at the same position are caused by inhibition of primer extension by a modified residue at that position or due to a strong secondary and/ or tertiary structure in that region. Numbers 54 and 55 on the side indicate the presence of $\Psi$ at these positions. T54 of a tRNA does not produce a dark band in either lane. Very dark bands at position 58 (marked) in both lanes in most tRNAs are due to the presence of $m^{1} A$, which significantly inhibits primer extension. Tm at position 54 also inhibits primer extension, which causes dark bands in both lanes in Lys tRNAs. (C) HeLa cell tRNA-enriched total RNAs were treated with AlkB to demethylate $\mathrm{m}^{1} \mathrm{~A} 58$, and then CMCT-primer extension was done as in A. Treatment (+) or no-treatment (-) by AlkB and CMCT is indicated beloweach lane. For unknown reasons, there is a strong stop at position 56 in tRNA ${ }^{T r}$, which becomes prominent after nearly complete demethylation of $m^{1} A 58$ by AlkB (compare with tRNA ${ }^{T r p}$ in A). Demethylation of $m^{1} A 58$ in the same $A$ lkB reaction mixture of tRNA-enriched total RNA is complete in tRNA ${ }^{\text {Trp }}$ and only partial in tRNA ${ }^{\text {Phe }}$.

extension. However, it does allow some extension after misincorporation during reverse transcription (Safra et al. 2017b). AlkB-mediated demethylation of $m^{1}$ A58 before CMCT treatment reduces the stops (dark bands) at posi- tion 58 and improves the resolution of $\Psi 54$ and $\Psi 55$ in some cases (Fig. 1C). Nucleotide sequences of some of these tRNAs are shown in Supplemental Figure S1A. Our data agree with the reported presence or absence of $\Psi 54$ in these tRNAs (Jühling et al. 2009).

\section{Human tRNA $\Psi 54$ synthase activity is selective toward certain tRNAs}

HeLa cell extract was used to treat $\left[\alpha-{ }^{32} \mathrm{P}\right] \mathrm{UTP}$-labeled transcripts of human tRNA ${ }^{T r p}$. After RNase T2 digestion and separation of the products by two dimensional (2D) thin layer chromatography (TLC), radioactive spots were seen for $\Psi$ and dihydrouridine (D), in addition to those for $A, C, G$, and $U$ (Fig. 2A). RNase T2 digestion of RNA produces ribonucleoside-3'-monophospates (Np). Consequently, in this nearest-neighbor analysis, labeled $5^{\prime}$ phosphate, originally derived from the $\left[\alpha-{ }^{32} \mathrm{P}\right]$-labeled NTP used to produce the transcript, is transferred to the $3^{\prime}$ side of the preceding residue. Therefore, labeled $U$ (or modified $U$ ) spots in the RNase T2 digest of [ $\alpha{ }^{32}$ P]UTP-labeled RNA would be derived from the first of two adjacent U's in the RNA sequence. Such adjacent pairs of $U$ in human tRNA ${ }^{\operatorname{Tr} p}$ are present at positions 47-48 and 54-55 (Supplemental Fig. S1A). We believe that the HeLa cell extract converted U at positions 47 and 54 to $D$ and $\Psi$, respectively, because although the modification status of human tRNA ${ }^{T r p}$ is not known, bovine tRNA ${ }^{\text {Trp }}$ has D47 and $\$ 54$ (Jühling et al. 2009). $\Psi$ at position 54 was confirmed by conversion of this $\Psi$ to 1-methyl- $\Psi\left(\mathrm{m}^{1} \Psi\right)$ by $M$. jannaschii TrmY, which converts the $\Psi 54$ of tRNA to $m^{1} \Psi$ (Chatterjee et al. 2012). We further confirmed that this $\Psi$ is derived from $U 54$ by using the tRNA ${ }^{\text {Trp }}$ of Haloferax volcanii, an archaeon (Fig. 2A). This tRNA only has two adjacent U's, at positions 54-55 and the nucleotide sequences of these two tRNA ${ }^{T r p}$ are nearly identical at positions 28-42 in the anticodon arm and 5361 in the TYC arm (Supplemental Fig. S1A). As expected, TLC analysis of $H$. volcanii tRNA ${ }^{T r p}$ showed a $\Psi$ but no D (Fig. 2A). This $\Psi$ could also be converted to $m^{1} \Psi$. We interchangeably used these two Trp tRNAs, since they provided similar results.

HeLa cell extract treatment of human tRNA ${ }^{\text {Ala }}$ did not generate any $\Psi$ (Fig. 2A). However, similar treatment of human tRNA ${ }^{\text {Phe }}$ did show a $\Psi$ (Fig. 2A). This $\Psi$ is not derived from position 54 because TrmY does not convert it to $\mathrm{m}^{1} \Psi$. Human tRNA ${ }^{\text {Phe }}$ contains two consecutive $U^{\prime}$ s at three positions: 16-17, 27-28, and 54-55 (Supplemental Fig. S1A). Native human tRNA ${ }^{\text {Phe }}$ contains $D, \Psi$, and $T$ at positions 16,27 , and 54, respectively. The $\Psi$ in our TLC is derived from $\Psi 27$, which is known to be produced by Pus1 (Rintala-Dempsey and Kothe 2017). We confirmed this by using a mutant tRNA ${ }^{\text {Phe, }}$, where U27 was changed to an A. No $\Psi$ was produced in this case (Fig. 2A).

Several other human tRNA transcripts were also treated with HeLa cell extracts and treated with TrmY, as needed, 
A - Extract

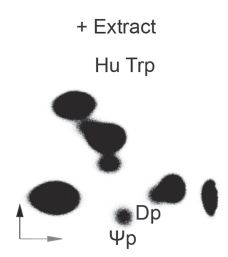

Hv Trp
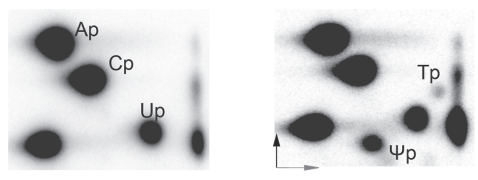

Hu Phe
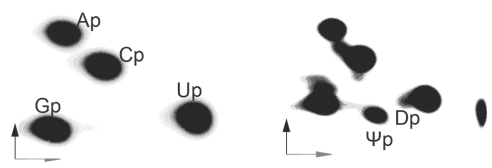

Hu Gln
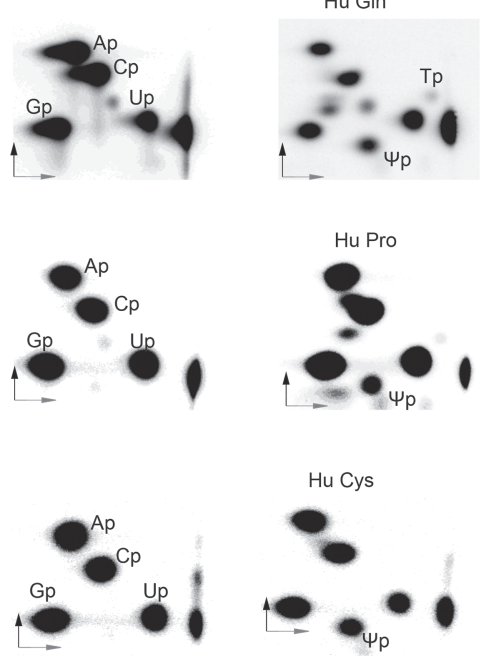

+ Extract + TrmY
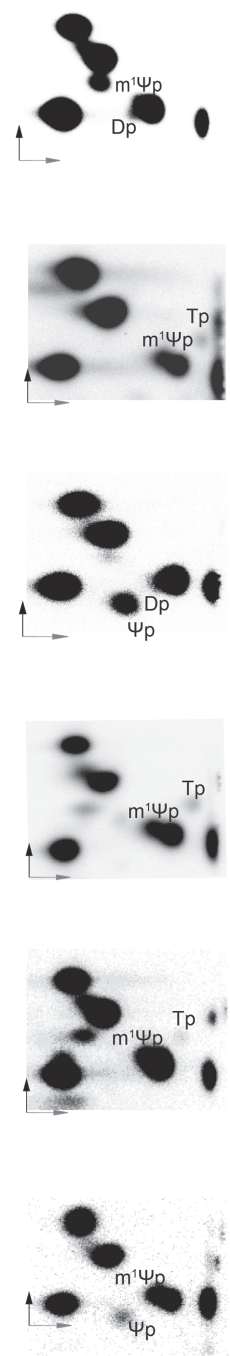

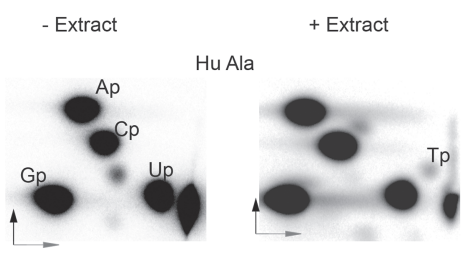

Hu Phe U27A

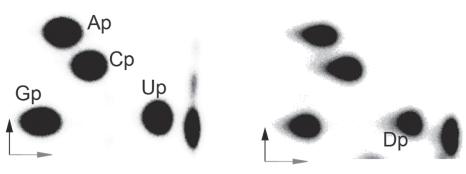

Hu Asp

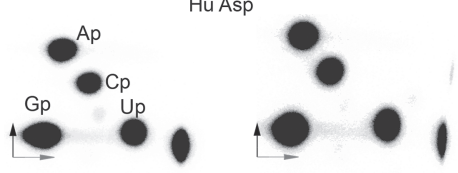

$\mathrm{Hu}$ Arg

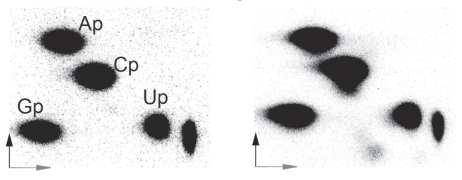

Hu Lys3

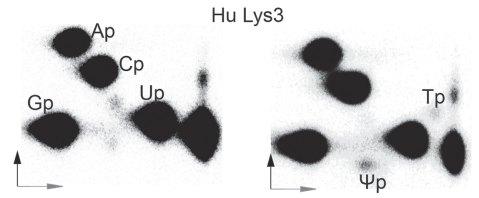

Hu Lys 1

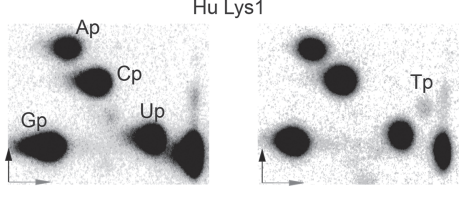

Hu Lys 1,2

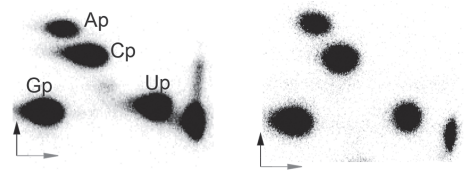

B

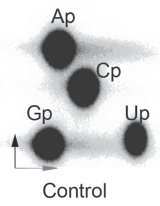

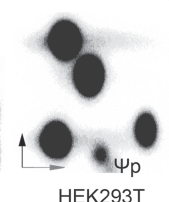

HEK293T
Hv Trp

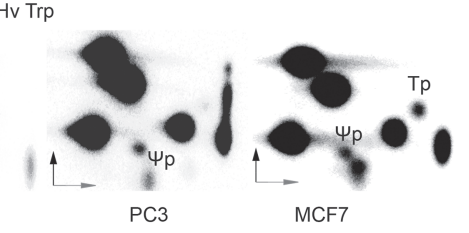

FIGURE 2. Human tRNA $\Psi 54$ synthase activity is selective. (A) Several $\left[\alpha{ }^{-}{ }^{32} \mathrm{P}\right] U T P$-labeled human $(\mathrm{Hu}) \mathrm{tRNA}$ and $H$. volcanii tRNA ${ }^{\mathrm{Trp}}$ (Hv Trp) transcripts (indicated above panels) were incubated with HeLa cell extracts. See sequences of transcripts in Supplemental Figure S1A. Purified RNA products were further treated with recombinant $M$. jannaschii TrmY and SAM, to convert $\Psi 54$ to $\mathrm{m}^{1} \Psi 54$, and the RNA products were further purified. RNase T2 digests of untreated (panels in the first column), extract-treated (panels in the second column), and extract and TrmY-treated RNAs (panels in the third column, for some transcripts) were separated by 2D-TLC using solvents I and II in the first and second dimensions (denoted by dark and light arrows), respectively. Representative autoradiograms of repeat experiments are shown. The labels indicate the 3'-monophospates of corresponding ribonucleosides. Trace amounts of Tp are observed in some reactions that are produced by conversion of U54 to T54 in the presence of residual SAM in the cell extracts. Sometimes Dp and $m^{1} \Psi p$ merge into Up. (B) Representative figures of 2D-TLC analyses of reactions similar to those in A using $\left[\alpha_{-}{ }^{32}\right.$ P]UTP-labeled $H$. volcanii tRNA ${ }^{\text {Trp }}$ transcripts and extracts of HEK293T, PC3, and MCF7 cells. 
to determine the production of $\Psi 54$ (Fig. 2A). $\Psi 54$ was produced in tRNA ${ }^{\text {Gln }}$ and tRNA ${ }^{\text {Pro }}$, but not in tRNA ${ }^{\text {Asp }}$ and tRNA ${ }^{\text {Arg }}$. The extracts did produce $\Psi 54$ in tRNA ${ }^{\text {Lys } 3,}$

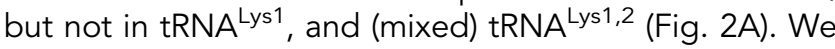
also used extracts of HEK293T, PC3, and MCF7 cells to show that tRNA $\Psi 54$ synthase activity is present in these cells too (Fig. 2B).

Overall these data suggest that human cell extracts can produce $\Psi 54$ in some isoacceptors of certain amino acids, but not of others.

\section{Human tRNA $\Psi 54$ synthase activity is in the cytoplasm}

We treated $\left[\alpha_{-}{ }^{32} \mathrm{P}\right]$ UTP-labeled $H$. volcanii RNA ${ }^{\text {Trp }}$ with nuclear and cytoplasmic extracts of HeLa cells. $\Psi$ was observed only when the cytoplasmic extract was used (Fig. $3 \mathrm{~A})$, suggesting that tRNA $\Psi 54$ synthase activity is restricted to the cytoplasm and not present in the nucleus. This was not due to lack of overall $\Psi$ synthase activity in the nuclear extracts, as observed by the presence of $\Psi$ in 1D-TLC of nuclease P1 digests of [ $\alpha-{ }^{32}$ P]UTP-labeled $H$. volcanii tRNA $^{\text {Trp }}$ treated with such extracts (Fig. 3B). Nuclease P1 generates labeled modified or unmodified versions of all $U^{\prime} s$ in $\left[\alpha-{ }^{32} P\right] U T P-l a b e l e d ~ R N A$. This $\Psi$ could come from any other position of tRNA, because several $\Psi$ synthases are present in the nucleus (Rintala-Dempsey and Kothe 2017). Our nuclear and cytoplasmic extracts did
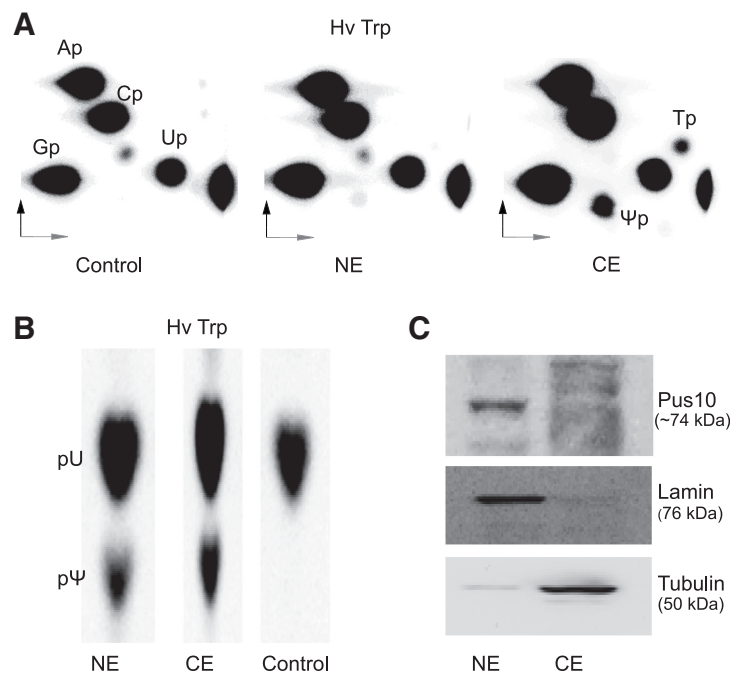

FIGURE 3. Human tRNA $\Psi 54$ synthase activity is present in the cytoplasm. 2D-TLC of RNase T2 (A) and 1D-TLC (in solvent I) of nuclease P1 (B) digests of HeLa nuclear (NE) and cytoplasmic (CE) extract-treated $\left[\alpha-{ }^{32}\right.$ P]UTP-labeled $H$. volcanii tRNA ${ }^{\text {Trp }}$ (Hv Trp). Relevant modified residues are labeled. " $p$ " before and after a nucleoside letter in $(A, B)$ indicates the $5^{\prime}$ and $3^{\prime}$ phosphate of that nucleoside. (C) Immunoblots of nuclear and cytoplasmic extracts using anti-Pus10 (HPA049582, Sigma) antibody. Purity of extracts was determined by using anti-lamin A (ab26300, Abcam) and anti-tubulin (ab6046, Abcam) antibodies as nuclear and cytoplasmic markers, respectively. not show any significant cross-contamination (Fig. 3C). Although tRNA $\Psi 54$ synthase activity was observed in the cytoplasm and not in the nucleus (Fig. 3A), immunoblots using anti-Pus10 antibody detected Pus10 in the nucleus and not in the cytoplasm (Fig. 3C). This inconsistency is discussed later. Addition of nuclear extract to cytoplasmic extract did not increase or decrease $\Psi 54$ synthesis. $\mathrm{m}^{1} \mathrm{~A} 58$ in the transcripts enhances $\Psi 54$ production (see later). However, nuclear extracts did not produce $\Psi 54$ even in $\mathrm{m}^{1} \mathrm{~A} 58$-containing tRNAs.

\section{Pus10 is the catalytic protein for tRNA $\Psi 54$ formation in human cells}

We treated $\left[\alpha^{-}{ }^{32}\right.$ P]UTP-labeled $H$. volcanii tRNA ${ }^{\text {Trp }}$ with extracts of two previously described Pus10-knockdown strains of PC3 cells (Jana et al. 2017) (along with a vector control) to determine any change in the amount of tRNA $\Psi 54$ synthesis. Both strains showed a reduction in $\Psi 54$ synthesis in comparison to controls, when measured relative to Pus1-mediated human tRNA ${ }^{\text {Phe }} \Psi 27$ synthesis by the same extracts (Fig. 4A; Supplemental Fig. S2A). We prepared a similar Pus10-knockdown strain of HEK293T cells (Supplemental Fig. S2B). It also showed reduced $\Psi 54$ synthesis (Fig. 4B; Supplemental Fig. S2C).

We transiently expressed a plasmid-borne codonchanged human Pus10 gene and its catalytic mutant (D344A) in a Pus10-knockdown strain of HEK293T cells. Some codons in the gene were replaced by synonymous codons to avoid shRNA-mediated knockdown of plasmid-borne gene-product. Although, both Pus10 proteins were expressed in the cells (Supplemental Fig. S2D), only the normal Pus10, not the mutant, rescued the tRNA $\Psi 54$ synthase activity of the extracts (Fig. 4C; Supplemental Fig. S2E). Even though the native Pus10 protein was not detected by the antiPus10 antibody in the cytoplasm (Fig. 3C), this overexpressed tagged Pus 10 protein was detected both in cytoplasm and nucleus by the antibody against its His-tag (Supplemental Fig. S2F). Overall these data suggest that human Pus 10 is the catalytic protein for tRNA $\Psi 54$ synthesis.

\section{Certain structural requirements are critical for tRNA Y54 synthase activity of human Pus10}

As mentioned previously, most tRNAs contain a consensus GUUCRANYC sequence at position 53-61. A predominant subset of this sequence in $\Psi 54$-containing animal tRNAs appears to be GUUCAAAUC. We changed U55 to an A or $A 58$ to a $G$ in $H$. volcanii tRNA ${ }^{T r p}$ and $A 57, A 59$, and U60 of human $\mathrm{TRNA} \mathrm{A}^{\mathrm{Tr}}$ to the other three bases and treated the transcripts with HeLa cell extracts (Fig. 5A). The U55A and A58G changes abolished $\Psi 54$ formation. The changes at positions 57,59 , and 60 considerably reduced $\Psi 54$ formation relative to unaltered tRNA. A triple change of these 

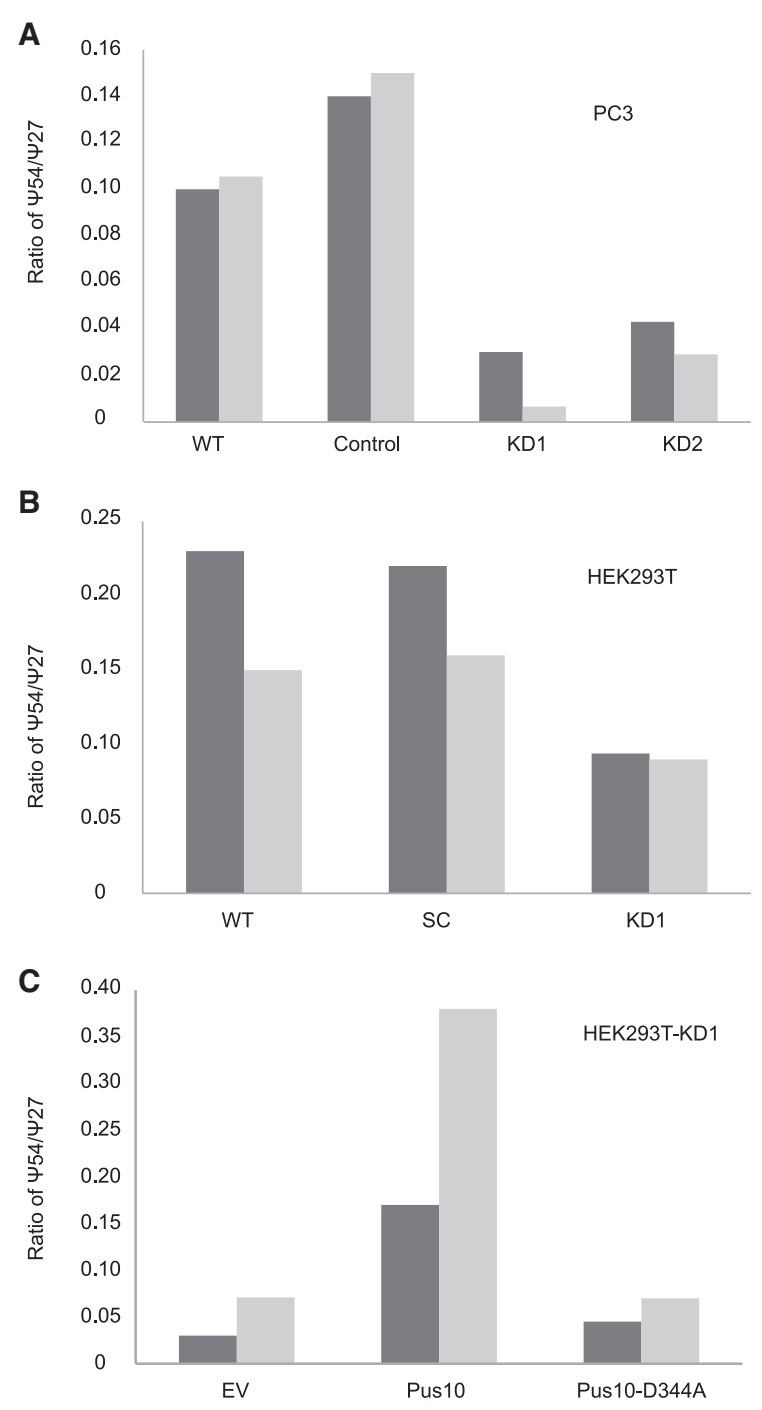

FIGURE 4. Human Pus 10 is the catalytic protein for tRNA $\Psi 54$ synthesis. (A) tRNA $\Psi 54$ synthase activity (percent $\Psi 54$ in tRNA ${ }^{\text {Trp }} /$ percent $\Psi 27$ in tRNA ${ }^{\text {Phe }}$ by the same extract) (see Supplemental Fig. S2A) by extracts of wild-type (WT), vector control (Control), and Pus10-knockdown (KD1 and KD2) strains of PC3 cells (dark bars-based on 2D-TLC analyses in Supplemental Fig. S2A; light bars-another independent replicate) showing reduction of $\Psi 54$ in knockdown cells. For an unknown reason, vector controls showed more activity than WT. (B) tRNA $\Psi 54$ synthase activity (dark bars-based on analyses in Supplemental Fig. S2C; light bars-another independent replicate) presented as in A using WT, scrambled control (SC), and Pus10-knockdown (KD1) strains of HEK293T. (C) tRNA $\Psi 54$ synthase activity (dark bars-based on analyses in Supplemental Fig. S2E; light bars-another independent replicate) as in A using HEK293T-KD1 cells transiently expressing codon-changed Pus10 and its D344A mutant. Transient transfection by empty vector (EV) was used to produce control cells.

three residues showed similar reduction. These results suggest that the tRNA $\Psi 54$ synthase activity prefers the 53-GUUCAAAUC-61 sequence and that U55 and A58 are absolutely necessary for this activity.

The crystal structure of human Pus10 predicts that it binds the acceptor stem of the tRNA (McCleverty et al.

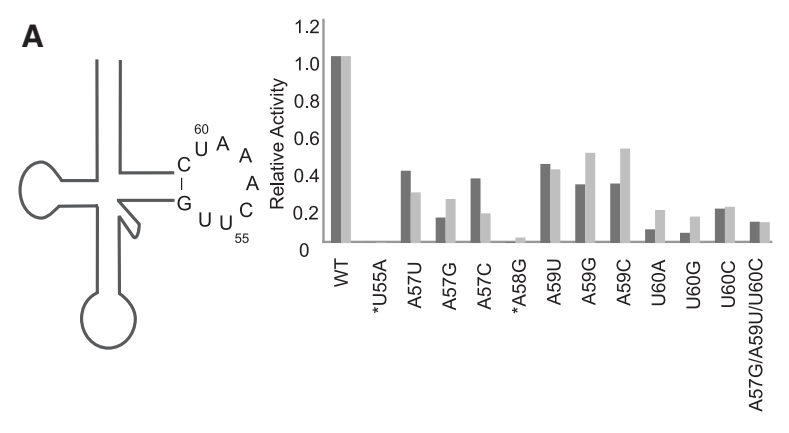

B
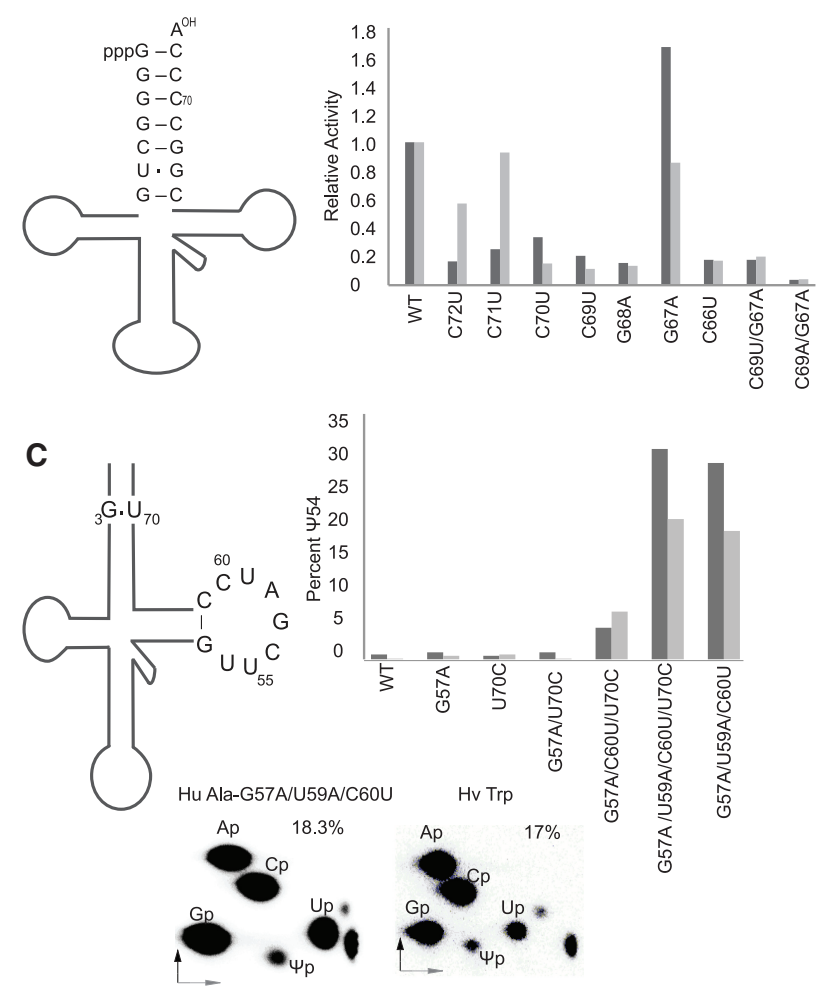

FIGURE 5. Importance of TYC loop sequence and stable structure of acceptor stem for tRNA $\Psi 54$ synthase activity of Pus10. (A) T $\Psi C$ loop mutants were assessed for $\Psi 54$ formation. RNase T2 digests of $\left[\alpha-{ }^{32} \mathrm{P}\right]$ UTP-labeled transcripts of different human and $\mathrm{H}$. volcanii (marked by *) tRNA ${ }^{\text {Trp }}$ mutants treated with HeLa cell extracts were separated by $2 \mathrm{D}-\mathrm{TLC}$, as in Figure 2A. U55A transcripts were $\left[\alpha_{-}{ }^{32} \mathrm{P}\right] \mathrm{ATP}$-labeled. The amount of $\Psi 54$ produced in each case was determined and is presented here in bar graphs as the relative activity ( $\Psi 54$ in mutant/ $\Psi 54$ in WT using the same extract). Dark and light bars are individual results of two independent experiments. Mutants of human and $\mathrm{H}$. volcanii tRNAs are compared with their own WT. The original (WT) TYC loop sequence of the transcript is shown on the left. (B) Acceptor stem mutants of $\left[\alpha_{-}{ }^{32} P\right] U T P-l a b e l e d ~ H$. volcanii tRNA ${ }^{\text {Trp }}$ transcripts were treated and the data are presented as in A. The original (WT) acceptor stem sequence of the transcript is shown on the left.

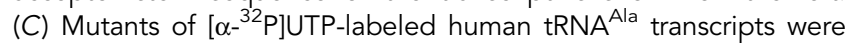
treated as in $A$ and the data are presented as percent of U54 converted to $\Psi 54$, not as relative activity, because the WT activity is negligible. The relevant sequence of the original (WT) transcript is shown on the left. Representative figures of 2D-TLC analyses of the $\left[\alpha^{-32} \mathrm{P}\right]$ UTPlabeled G57A/U59A/C60U mutant of tRNA ${ }^{\text {Ala }}$ and $H$. volcanii tRNA ${ }^{\text {Trp }}$ treated with the same HeLa extract are presented to show that the activity of the two transcripts are about the same. 
2007). We changed several base pairs in the acceptor stem of $H$. volcanii tRNA ${ }^{T r p}$ and determined their effects on $\Psi 54$ formation (Fig. 5B). There is a U6•G67 wobble pair in the original transcript. Changing it to U6-A67, making the stem fully Watson-Crick paired, slightly increased the amount of $\Psi 54$ formed. Two non-Watson-Crick pairs in the stem, i.e., one at U6•G67 and the other at any other place in the stem, drastically reduce $\Psi 54$ formation. Indeed, even if $\mathrm{U} 6 \bullet \mathrm{G} 67$ had been converted to WatsonCrick U6-A67, changing G4-C69 to either G4•U69 or G4•A69, showed that even a single non-Watson-Crick pair in the middle of the stem was sufficient to reduce the activity. In fact, the activity was nearly abolished when the pair was $\mathrm{G} 4 \bullet A 69$. These results suggest disruptions in the paired structure of the acceptor stem of a tRNA impede Pus10-mediated $\Psi 54$ synthesis.

To confirm the above-described requirements for $\Psi 54$ synthesis, we modified human tRNA ${ }^{\text {Ala }}$ to generate a

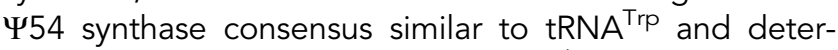
mined $\Psi 54$ formation (Fig. 5C). tRNA ${ }^{\text {Ala }}$ in all domains of life contains a $\mathrm{G} 3 \bullet \cup 70$ pair. The sequence of human tRNA ${ }^{\text {Ala }}$ at position 53-61 is GUUCGAUCC, which differs from the $\Psi 54$ synthase consensus sequence in having G57, U59, and C60, instead of A57, A59, and U60 (Supplemental Fig. S1A). Changing these three residues to the consensus, along with or without changing G3•U70 to G3-C70, brought the activity to about the same level as WT tRNA ${ }^{\text {Trp }}$ (Fig. 5C). Changing only two of these, i.e., G57A and C60U, along with U70C in the acceptor stem also gave some activity. G57A and U70C, either independently or in combination did not show activity.

To further confirm our results, we tested whether $\Psi 54$ can be produced in human tRNA ${ }^{\text {Cys }}$. The TUC loop sequence of human tRNA ${ }^{\text {Cys }}$ (based on its gene) matches the consensus sequence for $\Psi 54$ synthesis (Supplemental Fig. S1A). However, the sequence of any native animal tRNA $^{\text {Cys }}$ is not available. Therefore, the modification status of no animal tRNA ${ }^{\text {Cys }}$ is known. As we expected, $\Psi 54$ was produced in human tRNA ${ }^{\text {Cys }}$, which was confirmed by its conversion to $m^{1} \Psi$ by $\operatorname{Trm} Y$ (Fig. 2A). We believe the leftover $\Psi$ in this case (third column, Hu Cys in Fig. 2A) is derived from $\Psi 27$ produced by Pus1 present in HeLa cell extracts. Although the TUC loop sequence of human tRNA ${ }^{\text {Lys3 }}$ differs from the $\Psi 54$ synthase consensus sequence in having G59 instead of A59 (Supplemental Fig. S1A) and there is no report of the presence of $\Psi 54$ in tRNA ${ }^{\text {Lys3 }}$, our HeLa cell extracts could produce some $\Psi 54$ in its transcript (Fig. 2A). This is consistent with the results shown in Figure $5 \mathrm{~A}$, where $\mathrm{A} 59 \mathrm{G}$ mutation reduces, but does not abolish $\Psi 54$ synthesis.

All these results suggest that the 53-GUUCAAAUC-61 sequence of the TYC loop and the stable structure of the acceptor stem of tRNA are the major determinants for $\Psi 54$ synthesis.

\section{$m^{1} A 58$ modification in tRNA is very important for tRNA $\Psi 54$ synthesis by cell extracts}

Our cell extracts produced a mixture of $\Psi 54$ and T54 in tRNA transcripts (Figs. 2A, 6), although in vivo, these tRNAs contain only $\Psi 54$. This T54 is produced by Trmt2 methyltransferases normally present in the extracts. The amounts of T54 varied due to varying amounts of S-adenosyl-methionine (SAM) present in the extracts. Addition of SAM in the reactions increased the amount of T54 and reduced $\Psi 54$ (A58 + SAM in Fig. 6). Therefore, to suppress T54 production we added S-adenosyl-homocysteine (SAH), an inhibitor of SAM-dependent methyltransferases, to our reactions. As expected, it abolished T54, but surprisingly it also drastically reduced $\Psi 54$ (A58 + SAH in Fig. 6). We speculated that $\mathrm{SAH}$ is inhibiting $\mathrm{m}^{1} \mathrm{~A} 58$ formation, which may be a necessary precondition for in vivo $\Psi 54$ synthesis. Indeed, our cell extracts do produce $\mathrm{m}^{1} \mathrm{~A} 58$ (Supplemental Fig. S3A). We checked the effects of SAM and SAH on $\Psi 54$ production by cell extracts in $m^{1} A 58-c o n-$ taining transcripts. There was not much difference in $\Psi 54$ production between A58- and $\mathrm{m}^{1} \mathrm{~A} 58$-containing transcripts in the presence or absence of SAM (first four sets of bars in Fig. 6). However, $\Psi 54$ production was substantially increased in $\mathrm{m}^{1} \mathrm{~A} 58$-containing transcripts in the presence of $\mathrm{SAH}$, which inhibited both T54 and the $\mathrm{m}^{1} \mathrm{~A} 58$ methyltransferase activity of the extracts (compare the last two sets of bars in Fig. 6). All these data suggest that

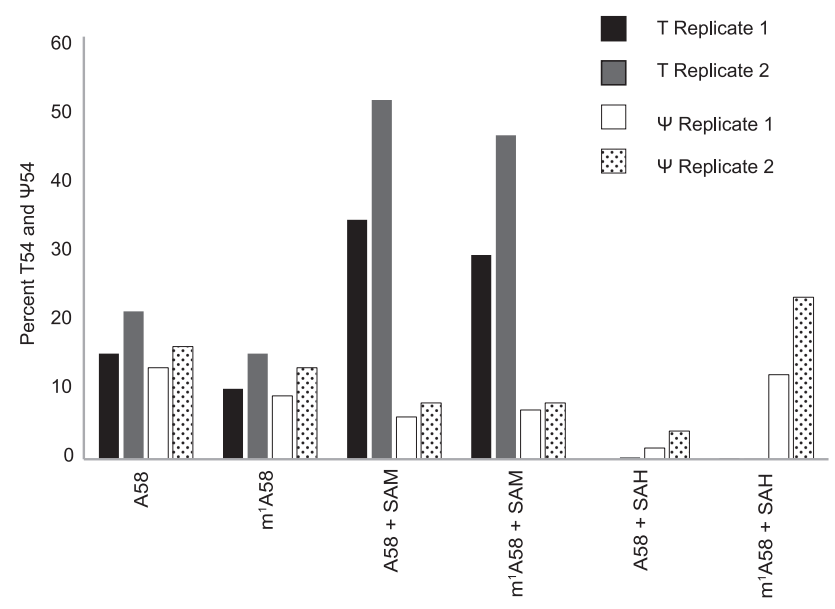

FIGURE 6. $m^{1} A 58$ in tRNA is needed for tRNA $\Psi 54$ formation by cell extracts. [ $\alpha{ }^{-}{ }^{32}$ P]UTP-labeled $H$. volcanii tRNA ${ }^{\text {Trp }}$ transcripts were first treated with $\mathrm{Trml}$ to produce $\mathrm{m}^{1} \mathrm{~A} 58$ and then treated with cell extracts in the presence of SAM or SAH. Trml does produce $m^{1} A 58$ in this transcript (Supplemental Fig. S3B). RNase T2 digests of the products were separated by 2D-TLC as in Figure 2A. The percentage of U54 converted to $\Psi 54$ and T54 were determined from the same 2D-TLC separation and are presented here in bar graphs. The presence of A (Trml-untreated) or $\mathrm{m}^{1} \mathrm{~A}$ (Trml-treated) at position 58 and the presence of SAM or SAH are indicated. Replicate 1 and 2 refer to two independent experiments. 
the tRNA $m^{1}$ A58 modification substantially increases $\Psi 54$ synthesis by cell extracts.

\section{Recombinant human Pus 10 can form $\Psi 54$ in select tRNAs and tRNA fragments}

Recombinant human Pus10 protein derived from E. coli cells did not show any tRNA $\Psi$ synthase activity (Supplemental Fig. S4). $\Psi 54$ or $\Psi 55$ was not produced even in the presence of $\mathrm{m}^{1} \mathrm{~A} 58$. However, recombinant human Pus10 from SF9 cells (Supplemental Fig. S5A) did show some $\Psi 54$ synthesis with the $H$. volcanii tRNA ${ }^{\text {Trp }}$ transcript, which was substantially enhanced when the transcript contained $m^{1} A 58$ (Fig. 7). This protein did not produce $\Psi 54$ in tRNA ${ }^{\text {Ala }}$, even when it contained $\mathrm{m}^{1} \mathrm{~A} 58$ (Fig. 7). However, it did produce $\Psi 54$ in a mutant of tRNA ${ }^{\text {Ala }}$, whose TIC loop was made similar to tRNA ${ }^{\text {Trp }}$ (Fig. 7). Treatment of a human tRNA ${ }^{\text {Lys3 }}$ transcript that has G59 instead of A59 in the $\Psi 54$ consensus (Supplemental Fig. S1A) with the recombinant Pus10 produced $\Psi 54$ in the transcript (Fig. 7) as seen before with cell extracts (Fig. 2A). This was enhanced when the transcript contained $\mathrm{m}^{1} \mathrm{~A} 58$. The recombinant protein also produced some $\Psi 54$ in human tRNA ${ }^{A r g}$ that has G57 and C59 instead of the A57 and A59 of consensus (Fig. 7). These results suggest that the SF9 cells-derived recombinant protein has the same specificity as the tRNA $\Psi 54$ synthase activity of the cell extracts and human Pus10 does not require any associated factor for its tRNA $\Psi 54$ synthase activity.

SF9 cells-derived recombinant Pus10 also produced some $\Psi 54$ equivalent in tRNA fragments that contained an acceptor stem and a TWC stem either contiguous or having a bulge between the two (tRNA-32 and tRNA-39 in Supplemental Fig. S1B and Fig. 7). The amount significantly increased in tRNA-39 that contained the $m^{1} A 58$ equivalent modification. Therefore, it appears that the acceptor stem, but not the other parts of a tRNA, makes some contribution in $\Psi 54$ synthesis. We did not study 54 production in tRNA fragments by cell extracts because these RNAs were degraded by the extracts.

These results with different tRNAs and tRNA fragments also suggest that the $\Psi 54$ catalytic activity of the recombinant Pus10 does not absolutely require $\mathrm{m}^{1} \mathrm{~A} 58$ modification, but is substantially increased by it.

\section{Recombinant human Pus10 can also form $\Psi 55$ in tRNAs and tRNA fragments}

Recombinant human Pus10 from SF9 cells also showed robust $\Psi 55$ synthesis in $H$. volcanii tRNA ${ }^{\text {Trp }}$ and human tRNA ${ }^{\text {Ala }}$ transcripts, which was not significantly enhanced when the transcript contained $m^{1} A 58$ (Fig. 8A). This was determined by nearest-neighbor analyses of [ $\left.\alpha-{ }^{32} \mathrm{P}\right] \mathrm{CTP}-\mathrm{la}-$ beled transcripts. The absence of any $\Psi$ production in nuclease P1 digests of the $\left[\alpha_{-}{ }^{32}\right.$ P]UTP-labeled U55A mutant

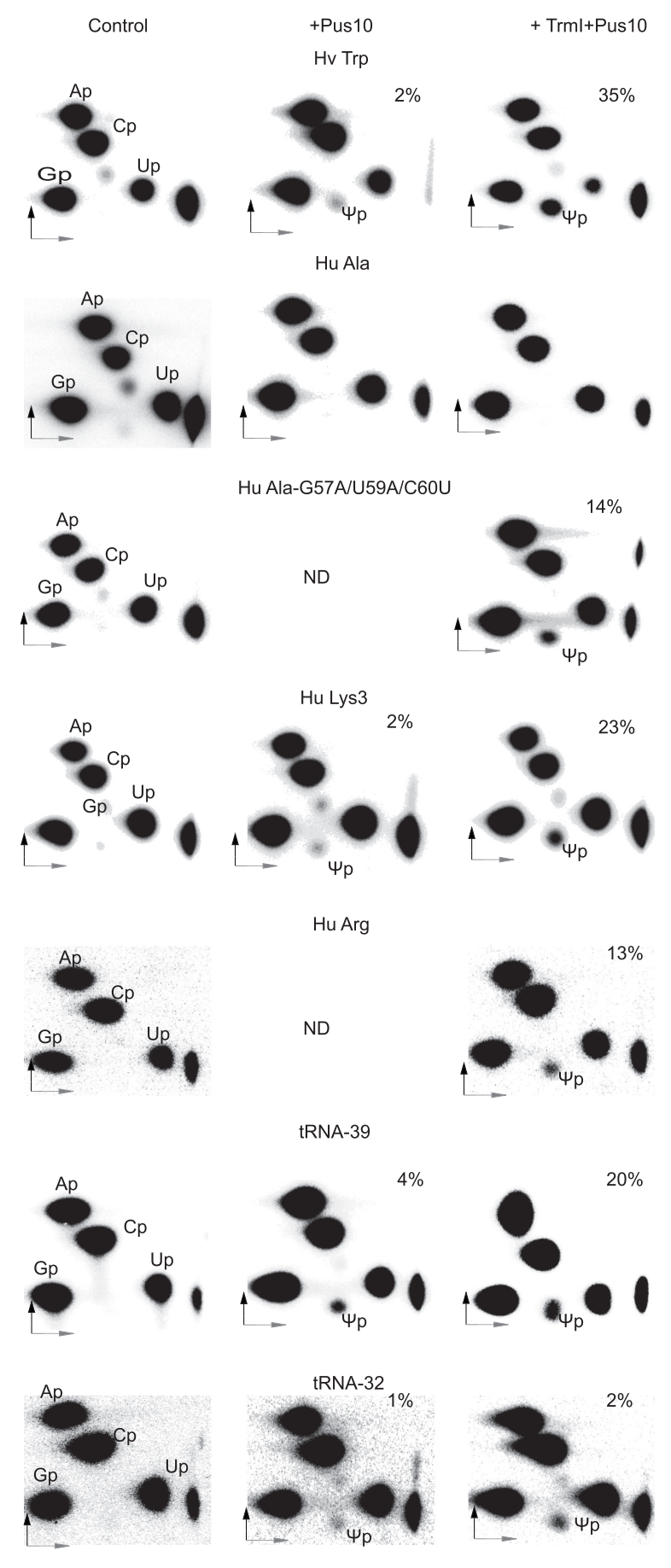

FIGURE 7. Recombinant human Pus10 produced in SF9 cells can synthesize tRNA $\Psi 54$ in select tRNAs and tRNA fragments. Different $\left[\alpha^{-32}\right.$ P]UTP-labeled transcripts (indicated above panels) after Trml treatment (to produce $\mathrm{m}^{1} \mathrm{~A} 58$ ) or without Trml treatment were incubated with SF9 cells-derived recombinant human Pus10, and RNase T2 digests of the products were separated by 2D-TLC as in Figure 2A. We confirmed Trml-mediated $\mathrm{m}^{1} \mathrm{~A} 58$ production in several of these transcripts (Supplemental Fig. S3B). Hu Ala-G57A/U59A/ $\mathrm{C60U}$ is the same mutant shown in Figure 5C. tRNA-32 is a fragment of $H$. volcanii tRNA ${ }^{T r p}$ containing only the TUC and anticodon arms, and tRNA-39 is the tRNA-32 with a seven-base bulge between the two arms (see sequences in Supplemental Fig. S1B). The percent $\Psi 54$ produced in each case is indicated. ND, not determined. 


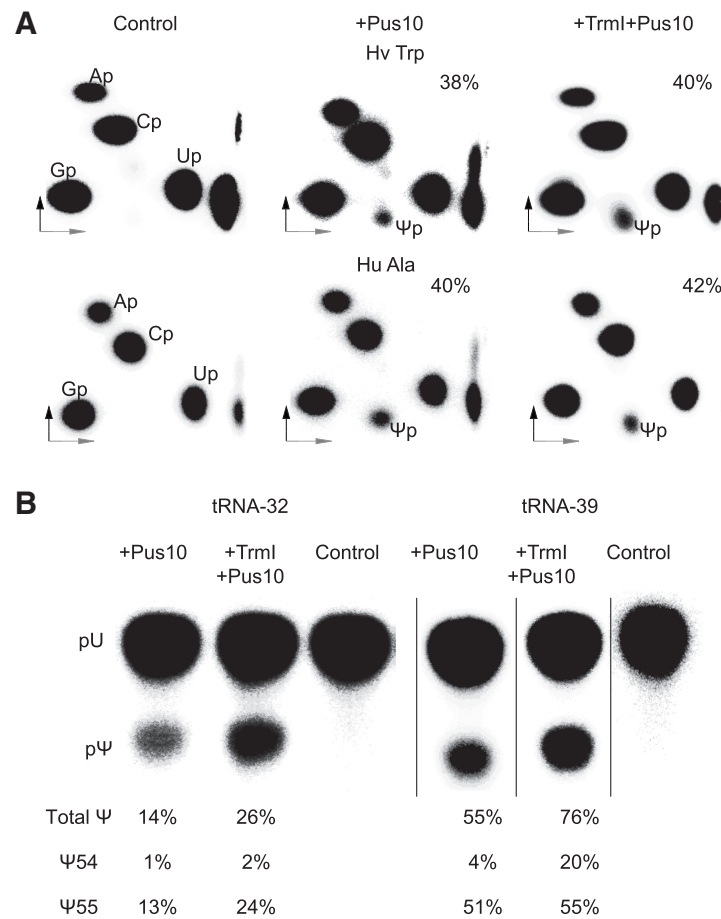

FIGURE 8. SF9 cells-derived recombinant human Pus10 has tRNA $\Psi 55$ synthase activity. $(A)\left[\alpha_{-}{ }^{32}\right.$ P]CTP-labeled $H$. volcanii tRNA ${ }^{\text {Trp }}$ and human tRNA ${ }^{\text {Ala }}$ transcripts (indicated above panels) after Trml treatment or without Trml treatment were incubated with SF9 cells-derived recombinant human Pus 10 and RNase T2 digests of the products were separated by 2D-TLC as in Figure 2A. $\Psi$ here is derived from position 55 of the tRNAs, because the only common UC sequence in the two tRNAs is at position 55-56 (Supplemental Fig. S1A). The percent $\Psi 55$ produced in each case is indicated. (B) Reaction products of [ $\left.\alpha-{ }^{32} \mathrm{P}\right] \mathrm{UTP}-\mathrm{la}-$ beled tRNA-32 and tRNA-39, in addition to the RNase T2 digestion shown in Figure 7, were also digested by nuclease P1, separated by $1 \mathrm{D}-\mathrm{TLC}$, and the total amount of $\Psi$ produced was determined. The amount of $\Psi 55$ produced was calculated by subtracting the amount of $\Psi 54$ determined from the TLC separations represented in Figure 7.

of $H$. volcanii tRNA ${ }^{\text {Trp }}$ (Supplemental Fig. S6) confirmed that recombinant Pus 10 has both $\Psi 54$ and $\Psi 55$ synthase activity. $\Psi 55$ is not produced here because of the absence of its substrate $U 55$, and $\Psi 54$ is not produced, because as observed with the cell extracts (U55A in Fig. 5A), recombinant Pus 10 also requires the presence of U55 to produce $\Psi 54$. Recombinant protein can also produce some $\Psi 55$ equivalent in tRNA-32 and tRNA-39, the tRNA fragments containing acceptor and T $\Psi \mathrm{C}$ stems (Fig. 8B). Overall these results suggest that the recombinant Pus10 can produce $\Psi 55$ even in those tRNAs where it cannot produce $\Psi 54$, e.g., tRNA ${ }^{\text {Ala }}$, and so, the specific $\Psi 54$ recognition sequence is not required for $\Psi 55$ formation.

\section{Cellular Pus10 and active recombinant Pus10 are larger than their predicted sizes}

Although $\Psi$ synthesizing Pus10 protein cannot be detected in the cytoplasm by immunoblotting (Fig. 3C), both nonfunctional $E$. coli-derived and functional SF9 cells-derived human Pus10 can be detected by anti-Pus10 antibody (Supplemental Fig. S5B). The predicted sizes of the two recombinant proteins are about the same, but the SF9 cells-derived protein appears to be larger in immunoblots than the E. coli-derived protein (Supplemental Fig. S5B). The native cellular protein (presumably nuclear Pus10, see Fig. 3C) is also substantially larger than the size predicted by its open reading frame (Supplemental Fig. S5B). Furthermore, cytoplasmic Pus10 is expected to be of the same size as the nuclear Pus10, because Histagged proteins that are observed in both nucleus and cytoplasm after transient transfection are of about the same size (Supplemental Fig. S2F).

\section{DISCUSSION}

\section{Nuclear and cytoplasmic versions of human Pus10 have different activities}

Previously, we showed by immunofluorescence and immunoblotting that human Pus10 is mainly present in the nucleus, and that it translocates to the mitochondria during TRAIL-induced apoptosis (Jana et al. 2017). Here again, by immunoblotting, we detect Pus 10 only in the nucleus (Fig. 3C). However, we observed $\Psi 54$ synthase activity only in the cytoplasmic extracts and not in the nuclear extracts. Knockdown and subsequent rescue experiments indicate this activity is due to Pus10. Although anti-Pus10 antibody did not detect native Pus10 in the cytoplasm (Fig. 3C), anti-His antibody could detect His-tagged Pus10 both in the nucleus and in the cytoplasm when Pus10 was transiently overexpressed in a knockdown cell line (Supplemental Fig. S2F). These observations about the locations of the Pus10 suggest that there are at least two different versions of Pus 10 and that the anti-Pus 10 antibody used here detects only the nuclear version. Nuclear and cytoplasmic Pus 10 are distinct because the addition of nuclear extract to cytoplasmic extract does not alter $\Psi 54$ synthase activity of the latter. The two versions of human Pus10 appear to harbor two distinct but apparently unrelated activities, pseudouridylation by cytoplasmic Pus 10 and involvement of nuclear Pus10 in apoptosis.

Nuclear and cytoplasmic versions of the Pus10 protein are not the products of paralogous genes. We reported previously (Fitzek et al. 2018) that only a single pus 10 gene per genome is observed both in archaeal and eukaryotic genomes. This is despite the occurrence of many genome duplications that have occurred during evolution of several eukaryotic lines. We believe that both versions of the protein are post-translationally modified and the modifications of the two versions are not identical. Our reasoning is based on the following. The predicted size of the E. coli-derived inactive Pus10 (Supplemental Fig. S5B) is $63.76 \mathrm{kDa}$ (including purification tags). The predicted size 
of the cellular Pus10 (presumably nuclear) is $60.24 \mathrm{kDa}$, but it appears larger than E. coli-derived Pus10 (Supplemental Fig. S5B), suggesting that it has post-translational modifications. Similarly, SF9 cells-derived Pus10 is expected to be $64.46 \mathrm{kDa}$ (including purification tags), but it also appears to be larger than its expected size (Supplemental Fig. S5B), again suggesting that it has post-translational modifications. Since (presumably) unmodified E. coli-derived protein is inactive and SF9 cells-derived protein can produce $\Psi$, we believe that cytoplasmic $\Psi$ synthesizing Pus10 protein would also have post-translational modifications. However, the modifications of the SF9 cells-derived and human cytoplasmic proteins appear to be somewhat different, such that the anti-Pus10 antibody can recognize the former but not the latter.

In principle, nuclear and cytoplasmic Pus10 could be splice variants of the same gene product. However, based on the available information (https://www.proteinatlas.org/ ENSG00000162927-PUS10/cell\#human and http://useast. ensembl.org/Homo_sapiens/Transcript/ProteinSummary? $\mathrm{db}=$ core; $g=$ ENSG00000162927; $r=2: 60940222-61018259$; $\mathrm{t}=$ ENST00000421319), this is less likely. Human Pus10 is reported to have six splice variants. Of these, only four are protein coding, two of which give rise to annotated full length Pus10 (529 aa), and the other two are expected to produce proteins of 62 aa and 120 aa. Alignment of the shorter versions with the 529 amino acid version suggest that they match with only the $N$ terminus of human Pus10, which would not contain the catalytic domain of the protein (McCleverty et al. 2007). The epitopes of the antibodies used in our study would not detect these smaller proteins. Human Pus10 splice variants that code for the 529 aa protein contain 18 exons.

\section{Mammalian tRNAs containing the sequence 57-AAAU-60 have $\Psi$ at position 54}

All sequenced mammalian tRNAs that have 57-AAAU-60 (part of 53-GUUCAAAUC-61) contain $\Psi 54$ instead of T54 (Jühling et al. 2009). Our transcripts containing this sequence also produced maximum levels of $\Psi 54$ (Fig. 5A). However, our extracts produced some T54 in all tRNA transcripts, even where $\Psi 54$ was also produced. The T54 and 54 modifications in a tRNA are mutually exclusive and cannot be directly interconverted. Therefore, cells in vivo must have some mechanism that does not allow U54 to T54 conversion in 57-AAAU-60-containing tRNAs.

\section{Requirement of the 57-AAAU-60 sequence for tRNA $\Psi 54$ synthesis is probably relaxed in dividing and virus-infected cells}

We could not produce $\Psi 54$ in tRNA ${ }^{\text {Lys } 1,2}$ by either cell extracts or recombinant Pus10 protein. This tRNA has 57GAGC-60 (Supplemental Fig. S1A). However, as men- tioned before, the amount of tRNA ${ }^{\text {Lys2 }}$ increases in SV40transformed mouse fibroblast cells and other dividing and proliferating tissues (Raba et al. 1979). This increased tRNA contains some $\Psi 54$ (Raba et al. 1979), suggesting Pus10 may modify this tRNA under certain conditions. Similarly, one mouse leukemia tRNA ${ }^{\text {Arg }}$ has been shown to contain $\Psi 54$ (Harada and Nishimura 1980). We could produce $\Psi 54$ in the same tRNA ${ }^{A r g}$ isoacceptor by recombinant protein (Fig. 7). This tRNA has 57-GACU-60 (Supplemental Fig. S1A). Using a primer corresponding to this tRNA ${ }^{\text {Arg }}$, we could also detect $\Psi 54$ in mouse liver tRNAs (Fig. 1). These reports suggest that certain tRNAs increase in dividing and virus-infected cells and at least a fraction of these tRNAs may contain $\Psi 54$, even if they do not contain the 57-AAAU-60 sequence. It is possible that a similar situation may exist in metabolically active tissues, e.g., liver cells. Probably certain factors or conditions in these cells relax the 57-AAAU-60 requirement of Pus 10 -mediated $\Psi 54$ synthesis. This may be possible because some tRNA genes for most amino acids in animal genomes contain sequences that differ from 57-AAAU-60 only at one position (Jühling et al. 2009), and we showed (Fig. 5A) that variation at one position (except A58) from this 57-AAAU-60 reduces, but does not abolish $\Psi 54$ synthesis.

\section{tRNA $\Psi 54$ and $m^{1}$ A58 modifications may be associated with retroviral DNA synthesis}

I54-containing tRNAs for Trp, Pro, and GIn of the host cell have been identified as primers for replication of retroviruses (Harada et al. 1975, 1979; Hu and Dahlberg 1983; Colicelli and Goff 1986; Marquet et al. 1995; Mak and Kleiman 1997). In addition, tRNAs for Lys are also suggested as primers for certain retroviruses-tRNA ${ }^{\text {Lys } 1,2}$ for Mason-Pfizer monkey virus and human foamy virus, and tRNA ${ }^{\text {Lys } 3}$ for mouse mammary tumor virus and lentiviruses, including HIV (Marquet et al. 1995; Mak and Kleiman 1997). These mammalian Lys tRNAs are reported to contain Tm54 (Raba et al. 1979; Jühling et al. 2009). However, as mentioned before, tRNA ${ }^{\text {Lys2 }}$ can have $\Psi 54$ under certain conditions (Raba et al. 1979) and we could produce $\Psi 54$ in tRNA ${ }^{\text {Lys3 }}$ both by using cell extract and recombinant protein (Figs. 2A, 7), suggesting that $\Psi 54$ can be produced even in Lys tRNAs. To initiate DNA synthesis, 18 residues at the $3^{\prime}$ end of the primer tRNA pair with the primer binding site (PBS) of the viral genome and $m^{1} A 58$ of the tRNA terminates plus-strand strong-stop synthesis (Renda et al. 2001). The $m^{1} A 58$ also appears to be necessary for $\Psi 54$ synthesis in vivo, because suppression of $\mathrm{m}^{1} \mathrm{~A} 58$ formation by $\mathrm{SAH}$, inhibits $\Psi 54$ activity of cell extracts (Fig. 6). In HIV, several tRNAs are packaged in the virus but only tRNA ${ }^{\text {Lys } 3}$ functions as a primer (Jiang et al. 1993; Eckwahl et al. 2016). HIV is known to modulate the tRNA pool to improve the translation efficiency of its late proteins (van Weringh et al. 2011). Therefore, theoretically HIV might 
also increase the population of $\Psi 54$-containing tRNA ${ }^{\text {Lys3 } 3}$, if present in low amounts, as is the case for tRNA ${ }^{\text {Lys2 }}$ in some cells (Raba et al. 1979). tRNA ${ }^{\text {Lys3 }}$ tightly associates with the HIV genome (Jiang et al. 1993). So far, the identity of the residue at position 54 of this tightly associated population of tRNA ${ }^{\text {Lys3 }}$ has not been determined. It could be Tm or $\Psi$.

$\Psi 54$ also appears to be involved in the interaction of tRNA with the retroviral reverse transcriptase, because interaction of avian and mammalian RRNA $^{\text {Trp }}$ with avian myeloblastosis virus reverse transcriptase either requires or is stabilized by $\Psi$ at positions 54 and 55 (Hu and Dahlberg 1983). All retroviral RNA genomes contain a motif called the primer activation signal (PAS), which pairs with an 8nt segment (anti-PAS) of tRNA at positions 48-55, and this interaction is important for both primer selection and efficient reverse transcription (Beerens and Berkhout 2002). This anti-PAS element contains $\Psi 54$ and $\Psi 55$ in several primer tRNAs, e.g., tRNA ${ }^{T r p}$, tRNA ${ }^{\text {Pro }}$, and tRNA ${ }^{\text {Gln }}$ (Jühling et al. 2009).

\section{TruB and Pus10 in mammalian cells seem to have redundant $\Psi 55$ synthase activities}

The tRNA $\Psi 55$ synthase activities of Pus10 and TruB appear to be redundant, because they can both produce $\Psi 55$ in all tRNAs and recognize the same TUC arm sequence. Mammals have two paralogs of TruB, TruB1, and TruB2 (Zucchini et al. 2003; Rintala-Dempsey and Kothe 2017). TruB2 is present in the mitochondria (Antonicka et al. 2017) and probably produces $\Psi 55$ in all four (out of 22 total) human mitochondrial tRNAs that contain this modification (Suzuki and Suzuki 2014). We cannot distinguish $\Psi 55$ synthase activity of Pus10 from that of TruB1 in our extracts because active TruB1 is reported to be present in both nucleus and cytoplasm (Safra et al. 2017a).

\section{Pus10 may produce $\Psi$ in certain mRNAs}

The orthologs, Pus4 and TruB1 have been shown to produce $\Psi$ in mRNAs of yeast and mammals, respectively (Carlile et al. 2014; Schwartz et al. 2014; Safra et al. 2017a), in a consensus sequence GUUCNANNC (underlined $U$ is converted to $\Psi$ ). Both TruB and Pus10 produce

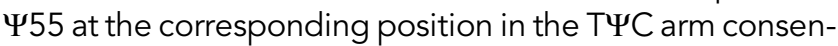
sus sequence GUUCRANYC, which is a subset of the mRNA consensus sequence. It is suggested that TruB1mediated $\Psi$ in mRNAs is predominantly produced in the nucleus (Safra et al. 2017a). In this case, these $\Psi$-containing mRNAs, when transported to the cytoplasm, would retain $\Psi$ till they are degraded, because $\Psi$ modification in RNA cannot be reversed. Therefore, it is possible that cytoplasmic versions of both TruB1 and Pus 10 could produce $\Psi$ in mRNAs under some inducible conditions that might have a regulatory role.
We observed that $m^{1} A 58$ in tRNA is required for $\Psi 54$ synthesis. Both these modifications occur in tRNA because the $\Psi 54$ consensus sequence GUUCAAAUC is a subset of the $m^{1} A$ consensus sequence GUUCNANNC observed in mRNAs in a 17-nt TYC arm-like stem-loop structure (Safra et al. 2017b). This association suggests that Pus10 may also convert the first $U$ of GUUCAAAUC in cytoplasmic mRNAs to $\Psi$ (equivalent to $\Psi 54$ of tRNAs) under inducible conditions, especially when $\mathrm{m}^{1} \mathrm{~A}$ is present in the mRNA four residues $3^{\prime}$ to the $\Psi$ site. There is evidence of the presence of two adjacent $\Psi^{\prime} \mathrm{s}$ in human mRNAs like OCIAD1, AK2, AKT1S1, and PMPCB (GEO accession number GSE60047) in a GUUCNANNC consensus motif (Schwartz et al. 2014). Possibly the first of the two $\Psi^{\prime}$ 's in these cases are produced by Pus 10.

Thus, to conclude, we have shown here that Pus10 is responsible for $\Psi 54$ production in certain mammalian tRNAs. This activity is enhanced by another tRNA modification ( $\left.m^{1} A 58\right)$. While this activity is generally dependent on a specific tRNA structural requirement, there exist certain exceptional conditions under which this requirement might be slightly relaxed. In addition to its tRNA $\Psi 54$ activity, we show evidence that mammalian Pus10 can also form tRNA $\Psi 55$. Based on several observations, we speculate that Pus10 may even produce $\Psi$ in certain mRNAs. Finally, there is compelling evidence supporting the possible association between tRNA $\Psi 54$ modification, and retroviral DNA synthesis. Our study demonstrating the function of Pus10 in tRNA modifications, opens up new questions for future studies, such as, whether the $\Psi 55$ activity of Pus 10 is just redundant with that of TruB1 or has a distinct role, whether Pus10-mediated tRNA modification is essential for DNA synthesis of HIV and other retroviruses, whether Pus10 is involved in the regulation of protein expression by modifying mRNAs in association with $\mathrm{m}^{1} \mathrm{~A}$ modification, and whether the two activities (RNA modification and a role in apoptosis) of Pus10 indicate a role of RNA modifications in apoptosis.

\section{MATERIALS AND METHODS}

Standard molecular biology procedures (Green and Sambrook 2012) were used unless specifically described. Oligonucleotides used in this work are listed in Supplemental Table S1.

\section{Determination of the presence of $\Psi$ at specific positions in tRNAs}

Total RNA from HeLa cells and C57BL/6 mouse livers was isolated using TRI Reagent according to the manufacturer's protocol. tRNAs were separated from other RNAs by PAGE on 6\% denaturing gel and eluted. The presence of $\Psi$ in the tRNA was determined by primer extension following CMCT treatment, as described previously (Majumder et al. 2016). Briefly, $20 \mu \mathrm{g}$ tRNA enriched total RNA ( $6 \mu \mathrm{g}$ tRNA and $14 \mu \mathrm{g}$ total RNA) was treated with CMCT for 20 min at $37^{\circ} \mathrm{C}$, while an untreated sample 
was simply incubated at $37^{\circ} \mathrm{C}$ for $20 \mathrm{~min}$ as control. After precipitation of the RNA, CMCT-treated samples were treated with 50 $\mathrm{mM} \mathrm{Na}{ }_{2} \mathrm{CO}_{3}, \mathrm{pH} 10.4$, for $3 \mathrm{~h}$ at $37^{\circ} \mathrm{C}$. Again, after precipitation, the RNAs were used for primer extension using $\left[5^{\prime}{ }^{32} \mathrm{P}\right]$-labeled primers (listed in Supplemental Table S1) that hybridized close to and on the $3^{\prime}$ side of the position to be mapped for $\Psi$. M-MLV reverse transcriptase (Promega) was used for primer extension according to the manufacturer's instructions. Reaction products were separated by $12 \%$ sequencing gels. CMCT forms adducts with $\Psi, U$, and $G$. Alkali removes all CMCT groups except those attached to $\mathrm{N}_{3}$ of $\Psi$. The extension stops at one residue before the CMCT modified $\Psi$. A dark band in CMCT-treated lane indicates the presence of $\Psi$ at that position. The position of the band in the gel that corresponds to $\Psi$ is determined by its distance from the end of the primer and correlation with the known sequence of the RNA. This method is not suitable for quantitation of $\Psi$ at a particular position in the RNA, because partial reaction conditions are used here for the CMCT reactions. Furthermore, reverse transcriptase reactions used for primer extensions show varying amounts of sensitivity to secondary structures and different modified residues present in the RNA, which can produce dark bands in both untreated and CMCT-treated lanes. We were not successful in conducting CMCT-primer extension analyses of tRNA ${ }^{\text {Ala }}$ and tRNA ${ }^{\text {Cys }}$. We believe this was due to the presence of four and five G's in the primers for these tRNAs that were needed to hybridize to four and five $C^{\prime} s$ in the $3^{\prime}$ regions of these tRNAs (see tRNA ${ }^{\mathrm{Ala}}$ and tRNA ${ }^{\text {Cys }}$ sequences in Supplemental Fig. S1A).

\section{DNA template construction and in vitro transcription}

All human $(\mathrm{Hu})$ tRNA genes were cloned in the pBluescript KS+ (Stratagene) vector between the EcoRI and HindIII sites. PCR products for cloning were prepared by using HeLa genomic DNA as template. tRNA PheU27A mutant was prepared by site directed mutagenesis. The previously described pVT9P11 $1 \mathrm{i}$ plasmid (Gurha et al. 2007) was used for H. volcanii (Hv) tRNA ${ }^{\text {Trp }}$. PCR-amplified DNAs using plasmids of tRNA gene clones (for Hu Trp, Hv Trp, Hu Phe, Hu PheT27A, Hu Lys1, Hu Lys3, Hu Gln, Hu Ala, Hu Asp, and Hu Cys) and HeLa genomic DNA (for $\mathrm{Hu}$ Pro, Hu Arg, and Hu Lys 1,2) as template were used for in vitro transcription to obtain tRNA transcripts. Forward primers for PCR contained T7 RNA polymerase promoter sequences. The same forward primers were used to prepare PCR products for variants of Hu Trp, Hv Trp, and Hu Ala (see Fig. 5) transcripts, but the reverse primer contained the desired mutations. PCR products of T7P oligonucleotide hybridized to HVTRP39-R and HVTRP32-R were used to generate the transcripts for tRNA-32 and tRNA39 , respectively. In vitro transcriptions to prepare ${ }^{32} \mathrm{P}$-labeled transcripts were carried out as described before (Gurha et al. 2007; Gurha and Gupta 2008).

\section{Pseudouridylation by cell extracts and thin layer chromatography}

To prepare total cell extracts, the cells were grown to $80 \%-90 \%$ confluency in $100 \mathrm{~mm}$ plates. The cells were trypsinized and collected by centrifugation at $500 \mathrm{~g}$ for $5 \mathrm{~min}$. Cells were washed with PBS (137 mM NaCl, $27 \mathrm{mM} \mathrm{KCl}, 8 \mathrm{mM} \mathrm{Na} 2 \mathrm{HPO}_{4}, 1.5 \mathrm{mM}$
$\left.\mathrm{KH}_{2} \mathrm{PO} 4\right)$. The cells were then suspended in buffer containing $10 \mathrm{mM}$ Tris-Cl, $\mathrm{pH}$ 7.5, $150 \mathrm{mM} \mathrm{KCl}, 3 \mathrm{mM} \mathrm{MgCl} 2,0.3 \% \mathrm{NP}-40$, $10 \%$ glycerol and protease and phosphatase inhibitor (Pierce A32961, 1 mini tablet/10 mL buffer), and incubated on ice for $10 \mathrm{~min}$. Cells were sonicated three times at $20 \times$ power for 15 sec each with 2 min incubation on ice after each sonication. This was followed by centrifugation at $18,000 \mathrm{~g}$ for $15 \mathrm{~min}$. The supernatant was aliquoted and flash frozen in liquid nitrogen and stored at $-80^{\circ} \mathrm{C}$ for enzymatic assays. Nuclear and cytoplasmic extracts were prepared as described previously (Jana et al. 2017) and supplemented with $10 \%$ glycerol before storage at $-80^{\circ} \mathrm{C}$. Protein concentrations of the extracts were determined by the Coomassie Protein Assay reagent (Thermo Scientific 1856209).

Activities of extracts were determined by treating 4 pmole of in vitro transcribed tRNAs with $200 \mu \mathrm{g}$ (protein) of extracts in a $50 \mu \mathrm{L}$ reaction containing $20 \mathrm{mM}$ Tris- $\mathrm{Cl}$, pH 7.5, 2 mM DTT, $120 \mathrm{mM}$ $\mathrm{KCl}$, and 1 unit of Ribolock (ThermoScientific EO0382). Assays were done at $37^{\circ} \mathrm{C}$ for $30 \mathrm{~min}$. The reactions were supplemented with $0.1 \mathrm{mM} \mathrm{SAM} \mathrm{(New} \mathrm{England} \mathrm{Biolabs} \mathrm{B9003S)} \mathrm{or} 0.1 \mathrm{mM} \mathrm{SAH}$ (Sigma A9384) as needed. The reactions were stopped by adding $150 \mu \mathrm{L}$ stop solution (0.2 mM EDTA, $0.1 \%$ SDS) followed by phenol-chloroform extraction, ethanol precipitation and digestion with RNase T2 or Nuclease P1. All assays were repeated twice. The data for each of the two independent experiments are presented in appropriate figures. Sometimes one control assay was used for multiple different assays when the same preparation of the labeled transcript was used for all those assays. The digests were resolved by two-dimensional thin-layer chromatography on cellulose plates (EMD Millipore) except for those in Supplemental Figure S2E, where PEI-cellulose plates (EMD Millipore) were used. The solvents used were Solvent I (isobutyric acid/0.5 $\mathrm{N} \mathrm{NH}_{4} \mathrm{OH}, 5: 3, v / v$ ) for the first dimension and Solvent II (isopropanol $/ \mathrm{HCl} / \mathrm{H}_{2} \mathrm{O}, 70: 15: 15, \mathrm{v} / \mathrm{v} / \mathrm{v}$ ) or Solvent III [0.1 M sodium phosphate, $\mathrm{pH} 6.8 /(\mathrm{NH} 4)_{2} \mathrm{SO}_{4} / \mathrm{n}$-propanol, 100:60:2, v/w/v] for the second dimension (Gupta 1984; Gurha et al. 2007; Gurha and Gupta 2008). Radioactivity in the plates was revealed and quantified by phosphorimaging using Optiquant software. The percent $\Psi$ or T produced in RNase T2 digests was determined by the formula: (radioactivity in $\Psi p$ or Tp spot $x$ the number of labeled nucleotides per transcript $\times 100) /($ sum of the radioactivity in all Np spots). The percent $\Psi$ produced in nuclease P1 digests was determined by the formula: (radioactivity in $\mathrm{p} \Psi$ spot $x$ the number of U's in the RNA $\times 100$ )/(sum of the radioactivity in $\mathrm{pU}$ and $\mathrm{p} \Psi$ spots).

\section{Preparation of HEK293T Pus10-knockdown strain and expression of Pus10 in the strain}

HeLa, MCF7 and PC3 cells were cultured as described previously (Jana et al. 2017). HEK293T cells were grown in DMEM media with $10 \% \mathrm{FBS}$ and $100 \mathrm{U} / \mathrm{mL}$ penicillin and $100 \mu \mathrm{g} / \mathrm{mL}$ streptomycin. Pus10 knockdown strains KD1 and KD2 of PC3 cells have been described before (Jana et al. 2017). These were prepared using shRNAs TRCN0000134366 and TRCN0000133677, respectively, and pLKO.1 (RHS4080) as control vector (all from ThermoFisher). Pus10 knockdown strain KD1 of HEK293T cells was prepared just as described before for PC3 cells (Jana et al. 2017) by using shRNA TRCN0000134366, and the scrambled 
control was prepared by using nontargeting shRNA RHS6848 (ThermoFisher). Human Pus10 (HuP10) cDNA clone (8069212) was purchased from Open Bio Systems Dharmacon, Lafayette, CO, USA, and used as a template for amplification of the HuP10 gene. It was cloned in pEF6/V5-His-TOPO (Invitrogen) between the $\mathrm{BamHI}$ and $\mathrm{Xbal}$ sites to have $\mathrm{V} 5$ and six-His tags at the $\mathrm{C}$ terminus of the protein. The Kozak sequence was added to the forward primer for expression in mammalian cells and the protein also has a TEV protease cleavage site. This clone was codon changed by site directed mutagenesis. A catalytic Asp to Ala mutant clone was generated by a second site directed mutagenesis. HuP10 clones were transiently transfected in HEK293T knockdown cells using Turbofect (ThermoFisher) and extracts were prepared after $48 \mathrm{~h}$ incubation.

\section{Cloning, purification and assays of recombinant Pus10}

Pus10 was PCR amplified from the above-described HuP10 clone in the pEF/V5-His-TOPO vector to include the V5 and 6-His tags, and cloned in pFastBac (Invitrogen) between the BamHI and Sstl sites. The PCR product generated was cut with Pmel and BamHI because HuP10 contains a restriction site for Sstl. Pmel and Sstl generate compatible overhangs for cloning. The Bac-to-Bac baculovirus expression system was used to overexpress the Pus10 protein. A bacmid was generated using the manufacturer's protocol (Invitrogen). SF9 cells were grown and transfected with the bacmid as described in the protocol (Invitrogen). Six hundred milliliters of SFX media was seeded with $1 \times 10^{6} \mathrm{cells} / \mathrm{mL}$, and 60 $\mathrm{mL}$ of the viral P2 stock was added to it and grown for $72 \mathrm{~h}$ at $27^{\circ} \mathrm{C}$ at $80 \mathrm{rpm}$. The cells were pelleted and suspended in lysis buffer (20 mM Tris-Cl, pH 8.0, $150 \mathrm{mM} \mathrm{NaCl}$, and 20\% glycerol) supplemented with EDTA free protease inhibitor (Pierce Protease Inhibitor, 88666, $1 \mathrm{mini}$ tablet/10 $\mathrm{mL}$ buffer). The suspension was sonicated three times at $20 \times$ power and the lysate was centrifuged at 14,000 rpm for $20 \mathrm{~min}$. The clear supernatant was bound to a pre-equilibrated Ni-NTA column with lysis buffer containing 3 $\mathrm{mM}$ imidazole. Binding was done by recirculation of the supernatant through the column for $1 \mathrm{~h}$. The column was washed with five column volumes of wash buffer $(20 \mathrm{mM}$ Tris-Cl, pH 8.0, $300 \mathrm{mM}$ $\mathrm{NaCl}, 20 \%$ glycerol, and $40 \mathrm{mM}$ imidazole). The protein was eluted in fractions in elution buffer $(20 \mathrm{mM}$ Tris-Cl, pH 8.0, $150 \mathrm{mM}$ $\mathrm{NaCl}, 20 \%$ glycerol, and $250 \mathrm{mM}$ imidazole). The eluted fractions were run on an SDS-PAGE gel and the fractions containing the protein were pooled together and dialyzed against dialysis buffer $(20 \mathrm{mM}$ Tris- $\mathrm{Cl}$, $\mathrm{pH} 8.0,100 \mathrm{mM} \mathrm{NaCl}, 3 \mathrm{mM} \mathrm{MgCl}$, $20 \%$ glycerol, $30 \mathrm{pM} \mathrm{ZnCl}$, and $2 \mathrm{mM}$ DTT). Concentrations of all recombinant proteins were determined by the Coomassie Protein Assay reagent.

The $\Psi$ synthase activities of recombinant protein were determined by treating 4 pmoles of in vitro transcribed RNA with 20 $\mu \mathrm{g}$ of Pus10 in a $50 \mu \mathrm{L}$ reaction consisting of $100 \mathrm{mM}$ Tris- $\mathrm{Cl}$, $\mathrm{pH}$ 8.0, $10 \mathrm{mM} \mathrm{MgSO}_{4}, 0.1 \mathrm{mM}$ EDTA, $100 \mathrm{mM} \mathrm{NH}_{4} \mathrm{OAc}, 0.5$ $\mathrm{mM}$ DTT at $37^{\circ} \mathrm{C}$ for $1 \mathrm{~h}$. The reaction was stopped by adding $150 \mu \mathrm{L}$ stop solution (0.2 mM EDTA, $0.1 \%$ SDS) followed by phenol-chloroform extraction and ethanol precipitation. Further RNase digestion and TLC were done as described for cell extract assays. E. coli-derived recombinant human protein, which did not show any $\Psi$ synthase activity, was prepared as described before
(Jana et al. 2017) and used under the same conditions as SF9 cells-derived protein.

\section{Other protein purifications and assays}

Trml was purified according to a published protocol (Droogmans et al. 2003). Briefly, a $200 \mathrm{~mL}$ culture was grown in LB media containing ampicillin to an $\mathrm{OD}_{600}=0.5$. IPTG was added to a final concentration of $1 \mathrm{mM}$ and cells were harvested after $3 \mathrm{~h}$ of IPTG induction. The cell pellet was suspended in $10 \mathrm{~mL}$ of Buffer A (50 mM Tris-Cl, pH 8.5, $500 \mathrm{mM} \mathrm{KCl)}$ and lysed by bursts of $30 \mathrm{sec}$ sonication for three times with storage of samples on ice for $2 \mathrm{~min}$ after each sonication. The lysate was cleared by centrifugation at $14,000 \mathrm{rpm}$ for $10 \mathrm{~min}$ at $4^{\circ} \mathrm{C}$. The supernatant was bound to a nickel column by recirculation for an hour. The column was washed with Buffer $A$ and protein was eluted using a gradient of $0-1 \mathrm{M}$ imidazole. The fractions containing protein were pooled together and dialyzed against buffer A containing 200 mM imidazole. High $\mathrm{KCl}$ and imidazole concentrations are needed to keep the protein soluble at high concentration (Droogmans et al. 2003). Aliquots of the enzyme were flash frozen in liquid nitrogen and stored at $-80^{\circ} \mathrm{C} \cdot \mathrm{m}^{1} \mathrm{~A} 58$ containing transcripts were prepared by slight modification of a published procedure (Droogmans et al. 2003). Four picomoles of labeled RNA was treated with 5 $\mu \mathrm{g}$ of $\mathrm{Trml}$ in a $100 \mu \mathrm{L}$ reaction consisting of $50 \mathrm{mM}$ Tris- $\mathrm{Cl}, \mathrm{pH}$ 8.0, $10 \mathrm{mM} \mathrm{MgCl} 2,0.5 \mathrm{mM} \mathrm{SAM}$ for $1 \mathrm{~h}$ at $60^{\circ} \mathrm{C}$. The reaction was stopped by phenol-chloroform extraction followed by ethanol precipitation.

AlkB was purified according to a slight modification of a published protocol (Hrabeta-Robinson et al. 2017). Briefly, E. coli BL21(DE3) pLysS was transformed with AlkB-AVA421 and grown to $A_{600}$ of 0.5 and induced with $1 \mathrm{mM}$ IPTG for $2 \mathrm{~h}$ at $37^{\circ} \mathrm{C}$. After harvesting the cells the pellet was suspended in sonication buffer (20 mM Hepes, pH 7.5, 5\% glycerol, $1 \mathrm{M} \mathrm{NaCl}, 2$ mM BME) and EDTA free protease inhibitor (Pierce, 88666, 1 mini tablet/10 $\mathrm{mL}$ buffer), sonicated thrice for $10 \mathrm{sec}$, and centrifuged at 10,000 rpm for $10 \mathrm{~min}$ at $4^{\circ} \mathrm{C}$. The supernatant was flash frozen and stored at $-80^{\circ} \mathrm{C}$. A no salt buffer $(5 \%$ Glycerol, $20 \mathrm{mM}$ Tris-Cl, $\mathrm{pH} 8,2 \mathrm{mM} \mathrm{BME}$ ) of equal volume was added to the frozen extract. The mixture was added to $200 \mu \mathrm{L}$ Talon resin prewashed in $0.5 \mathrm{M} \mathrm{NaCl}$ wash buffer (5\% Glycerol, $20 \mathrm{mM}$ Tris-Cl, $\mathrm{pH}$ 8, $0.5 \mathrm{M} \mathrm{NaCl}$, and $2 \mathrm{mM} \mathrm{BME}$ ) and rotated in a nutator for $1 \mathrm{~h}$. The resin bound protein was obtained by centrifugation at 4000 rpm for $5 \mathrm{~min}$. The resin was washed three times with $0.5 \mathrm{M}$ $\mathrm{NaCl}$ buffer. Nonspecific binding was removed by washing with $5 \mathrm{mM}$ imidazole containing buffer followed by suspending the resin in $10 \mathrm{mM}$ imidazole containing wash buffer and eluting in $300 \mathrm{mM}$ imidazole containing buffer. The protein was dialyzed against $20 \mathrm{mM}$ Tris-Cl, pH 8.0, 50\% glycerol, $200 \mathrm{mM} \mathrm{NaCl}$, and $2 \mathrm{mM}$ DTT. Twenty to forty micrograms of total RNA was treated with equal amounts $(20-40 \mu \mathrm{g})$ of AlkB in a $100 \mu \mathrm{L}$ reaction volume consisting of $50 \mathrm{mM}$ Hepes $\mathrm{KOH}, \mathrm{pH}$ 8.0, $75 \mu \mathrm{M}$ Ferrous ammonium sulfate, $\mathrm{pH} 5.0,1 \mathrm{mM}$ alpha-ketoglutarate, $2 \mathrm{mM}$ freshly prepared sodium ascorbate and $50 \mu \mathrm{g} / \mathrm{mL}$ of RNase/ DNase free BSA in a final concentration for $100 \mathrm{~min}$ at $37^{\circ} \mathrm{C}$. One hundred microliters of stop solution (11 mM EDTA, 200 $\mathrm{mM}$ ammonium acetate) was added to stop the reaction followed by phenol-chloroform and precipitation of RNA for downstream applications. 
The TrmY (Mj1640) protein was purified under denaturing conditions and used as described previously (Chatterjee et al. 2012).

\section{Immunoblotting and qPCR}

Immunoblotting and qPCR were done exactly as described previously (Jana et al. 2017). We used anti-Pus10 (HPA049582, Sigma) antibody for the immunoblots shown in Figure $3 \mathrm{C}$ and Supplemental Figure S5B. We also used another commercial antiPus10 (HPA044736, Sigma) antibody, but it showed too many nonspecific bands in both nuclear and cytoplasmic extracts and was not useful. Anti-HisTag antibody (2365S, Cell Signaling) was used to check for overexpressed Pus10.

\section{SUPPLEMENTAL MATERIAL}

Supplemental material is available for this article.

\section{ACKNOWLEDGMENTS}

We thank Eric Phizicky (University of Rochester) and Louis Droogmans (Université Libre de Bruxelles) for clones for recombinant AlkB and Trml, respectively, Judy Davie (Southern Illinois University) for providing mouse livers, pEF6/V5-His-TOPO vector, HEK293T cells, and allowing us to work in her facilities; Farid Kadyrov and Lyudmila Kadyrova (Southern Illinois University) for providing pFastBac1 vector, HeLa S3 and SF9 cells, and DH10B strain of E. coli; and David Clark (Southern Illinois University) for critical reading of the manuscript. This work was supported by the National Institute of General Medical Sciences, National Institutes of Health grant GM055945 to R.G.

Received July 16, 2018; accepted December 6, 2018.

\section{REFERENCES}

Antonicka H, Choquet K, Lin ZY, Gingras AC, Kleinman CL, Shoubridge EA. 2017. A pseudouridine synthase module is essential for mitochondrial protein synthesis and cell viability. EMBO Rep 18: 28-38. doi:10.15252/embr.201643391

Aza-Blanc P, Cooper CL, Wagner K, Batalov S, Deveraux QL, Cooke MP. 2003. Identification of modulators of TRAIL-induced apoptosis via RNAi-based phenotypic screening. Mol Cell 12: 627-637. doi:10.1016/S1097-2765(03)00348-4

Becker HF, Motorin Y, Planta RJ, Grosjean H. 1997. The yeast gene YNL292w encodes a pseudouridine synthase (Pus4) catalyzing the formation of $\Psi_{55}$ in both mitochondrial and cytoplasmic tRNAs. Nucleic Acids Res 25: 4493-4499. doi:10.1093/nar/25. 22.4493

Beerens N, Berkhout B. 2002. Switching the in vitro tRNA usage of HIV-1 by simultaneous adaptation of the PBS and PAS. RNA 8: 357-369. doi:10.1017/S1355838202028194

Blaby IK, Majumder M, Chatterjee K, Jana S, Grosjean H, de CrécyLagard V, Gupta R. 2011. Pseudouridine formation in archaeal RNAs: the case of Haloferax volcanii. RNA 17: 1367-1380. doi:10.1261/rna.2712811

Carlile TM, Rojas-Duran MF, Zinshteyn B, Shin H, Bartoli KM, Gilbert WV. 2014. Pseudouridine profiling reveals regulated mRNA pseudouridylation in yeast and human cells. Nature 515: 143-146. doi:10.1038/nature13802
Chatterjee K, Blaby IK, Thiaville PC, Majumder M, Grosjean H, Yuan YA, Gupta R, de Crécy-Lagard V. 2012. The archaeal COG1901/DUF358 SPOUT-methyltransferase members, together with pseudouridine synthase Pus10, catalyze the formation of 1methylpseudouridine at position 54 of tRNA. RNA 18: 421-433. doi:10.1261/rna.030841.111

Colicelli J, Goff SP. 1986. Isolation of a recombinant murine leukemia virus utilizing a new primer tRNA. J Virol 57: 37-45.

Droogmans L, Roovers M, Bujnicki JM, Tricot C, Hartsch T, Stalon V, Grosjean H. 2003. Cloning and characterization of tRNA ( $\left.{ }^{1} \mathrm{~A} 58\right)$ methyltransferase (Trml) from Thermus thermophilus HB27, a protein required for cell growth at extreme temperatures. Nucleic Acids Res 31: 2148-2156. doi:10.1093/nar/ gkg314

Eckwahl MJ, Arnion H, Kharytonchyk S, Zang T, Bieniasz PD, Telesnitsky A, Wolin SL. 2016. Analysis of the human immunodeficiency virus-1 RNA packageome. RNA 22: 1228-1238. doi: 10.1261/rna.057299.116

Fitzek E, Joardar A, Gupta R, Geisler M. 2018. Evolution of eukaryal and archaeal pseudouridine synthase Pus10. J Mol Evol 86: 7789. doi:10.1007/s00239-018-9827-y

Fournier M, Labouesse J, Dirheimer G, Fix C, Keith G. 1978. Primary structure of bovine liver tRNA ${ }^{\text {Trp }}$. Biochim Biophys Acta 521: 198208. doi:10.1016/0005-2787(78)90262-9

Fujikane R, Behm-Ansmant I, Tillault AS, Loegler C, Igel-Bourguignon $V$, Marguet $E$, Forterre $P$, Branlant $C$, Motorin $Y$, Charpentier B. 2018. Contribution of protein Gar1 to the RNAguided and RNA-independent rRNA: $\Psi$-synthase activities of the archaeal Cbf5 protein. Scientific Rep 8: 13815. doi:10.1038/ s41598-018-32164-0

Green MR, Sambrook J. 2012. Molecular cloning: a laboratory manual. Cold Spring Harbor Laboratory Press, Cold Spring Harbor, NY.

Grosjean H, Edqvist J, Stråby KB, Giegé R. 1996. Enzymatic formation of modified nucleosides in tRNA: dependence on tRNA architecture. J Mol Biol 255: 67-85. doi:10.1006/jmbi.1996.0007

Gupta R. 1984. Halobacterium volcanii tRNAs. Identification of 41 tRNAs covering all amino acids, and the sequences of 33 class I tRNAs. J Biol Chem 259: 9461-9471.

Gupta R. 1985. Transfer ribonucleic acids of archaebacteria. In The archaebacteria; the bacteria: a treatise on structure and function (ed. Woese CR, Wolfe RS), Vol. 8, pp. 311-343. Academic Press, New York.

Gupta R. 1986. Transfer RNAs of Halobacterium volcanii: sequences of five leucine and three serine tRNAs. Syst Appl Microbiol 7: 102-105. doi:10.1016/S0723-2020(86)80131-X

Gurha P, Gupta R. 2008. Archaeal Pus10 proteins can produce both pseudouridine 54 and 55 in tRNA. RNA 14: 2521-2527. doi: 10.1261/rna.1276508

Gurha P, Joardar A, Chaurasia P, Gupta R. 2007. Differential roles of archaeal box H/ACA proteins in guide RNA-dependent and independent pseudouridine formation. RNA Biol 4: 101-109. doi: 10.4161/rna.4.2.5177

Harada F. 1989. Nucleotide sequence of threonine tRNA from mouse leukemia cells. Nucleic Acids Res 17: 7517. doi:10.1093/nar/ 17.18.7517

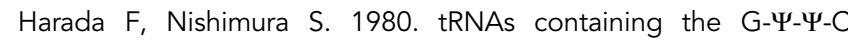
sequence. I. Two arginine tRNAs of mouse leukemia cells. Biochem Int 1: 539-546.

Harada F, Sawyer RC, Dahlberg JE. 1975. A primer ribonucleic acid for initiation of in vitro Rous sarcarcoma virus deoxyribonucleic acid synthesis. J Biol Chem 250: 3487-3497.

Harada F, Peters GG, Dahlberg JE. 1979. The primer tRNA for Moloney murine leukemia virus DNA synthesis. Nucleotide 
sequence and aminoacylation of tRNA ${ }^{\text {Pro }}$. J Biol Chem 254: 10979-10985.

Harada F, Matsubara M, Kato N. 1989. Nucleotide sequences of two glutamine tRNAs from HeLa cells. Nucleic Acids Res 17: 8371. doi:10.1093/nar/17.20.8371

Hrabeta-Robinson E, Marcus E, Cozen AE, Phizicky EM, Lowe TM. 2017. High-throughput small RNA sequencing enhanced by AlkB-facilitated RNA de-methylation (ARM-Seq). Methods Mol Biol 1562: 231-243. doi:10.1007/978-1-4939-6807-7_15

Hu JC, Dahlberg JE. 1983. Structural features required for the binding of tRNA ${ }^{\text {Trp }}$ to avian myeloblastosis virus reverse transcriptase. Nucleic Acids Res 11: 4823-4833. doi:10.1093/nar/11.14.4823

Jana S, Hsieh AC, Gupta R. 2017. Reciprocal amplification of caspase3 activity by nuclear export of a putative human RNA-modifying protein, PUS10 during TRAIL-induced apoptosis. Cell Death Dis 8: e3093. doi:10.1038/cddis.2017.476

Jiang M, Mak J, Ladha A, Cohen E, Klein M, Rovinski B, Kleiman L. 1993. Identification of tRNAs incorporated into wild-type and mutant human immunodeficiency virus type 1. J Virol 67: 32463253.

Joardar A, Jana S, Fitzek E, Gurha P, Majumder M, Chatterjee K, Geisler M, Gupta R. 2013. Role of forefinger and thumb loops in production of $\Psi 54$ and $\Psi 55$ in tRNAs by archaeal Pus10. RNA 19: 1279-1294. doi:10.1261/rna.039230.113

Jühling F, Mörl M, Hartmann RK, Sprinzl M, Stadler PF, Pütz J. 2009. tRNAdb 2009: compilation of tRNA sequences and tRNA genes. Nucleic Acids Res 37: D159-D162. doi:10.1093/nar/gkn772

Kamalampeta R, Kothe U. 2012. Archaeal proteins Nop10 and Gar1 increase the catalytic activity of Cbf5 in pseudouridylating tRNA. Sci. Rep 2: 663. doi:10.1038/srep00663

Kamalampeta R, Keffer-Wilkes LC, Kothe U. 2013. tRNA binding, positioning, and modification by the pseudouridine synthase Pus10. J Mol Biol 425: 3863-3874. doi:10.1016/j.jmb.2013.05.022

Keith G. 1984. The primary structures of two arginine tRNAs (anticodons C-C-U and $\mathrm{mcm}^{5} \mathrm{a}^{2} \mathrm{U}-\mathrm{C}-\psi$ ) and of glutamine tRNA (anticodon C-U-G) from bovine liver. Nucleic Acids Res 12: 2543-2547. doi:10.1093/nar/12.5.2543

Koonin EV. 1996. Pseudouridine synthases: four families of enzymes containing a putative uridine-binding motif also conserved in dUTPases and dCTP deaminases. Nucleic Acids Res 24: $2411-$ 2415. doi:10.1093/nar/24.12.2411

Kuchino Y, Beier H, Akita N, Nishimura S. 1987. Natural UAG suppressor glutamine tRNA is elevated in mouse cells infected with Moloney murine leukemia virus. Proc Natl Acad Sci 84: 26682672. doi:10.1073/pnas.84.9.2668

Majumder M, Bosmeny MS, Gupta R. 2016. Structure-function relationships of archaeal Cbf5 during in vivo RNA-guided pseudouridylation. RNA 22: 1604-1619. doi:10.1261/rna.057547.116

Mak J, Kleiman L. 1997. Primer tRNAs for reverse transcription. J Virol 71: 8087-8095.

Marquet R, Isel C, Ehresmann C, Ehresmann B. 1995. tRNAs as primer of reverse transcriptases. Biochimie 77: 113-124. doi:10.1016/ 0300-9084(96)88114-4

McCleverty CJ, Hornsby M, Spraggon G, Kreusch A. 2007. Crystal structure of human Pus10, a novel pseudouridine synthase. J Mol Biol 373: 1243-1254. doi:10.1016/j.jmb.2007.08.053

Mueller EG, Ferre-D'Amare AR. 2009. Pseudouridine formation, the most common transglycosylation in RNA. In DNA and RNA modification enzymes: structure, mechanism, function and evolution (ed. Grosjean H), pp. 363-376. Landes Bioscience, Austin, TX.

Muller S, Fourmann JB, Loegler C, Charpentier B, Branlant C. 2007. Identification of determinants in the protein partners aCBF5 and aNOP10 necessary for the tRNA: $\Psi 55$-synthase and RNA-guided
RNA: $\Psi$-synthase activities. Nucleic Acids Res 35: 5610-5624. doi:10.1093/nar/gkm606

Muller S, Leclerc F, Behm-Ansmant I, Fourmann JB, Charpentier B, Branlant C. 2008. Combined in silico and experimental identification of the Pyrococcus abyssi H/ACA sRNAs and their target sites in ribosomal RNAs. Nucleic Acids Res 36: 2459-2475. doi:10.1093/ nar/gkn077

Muthuswami R, Chen J, Burnett BP, Thimmig RL, Janjic N, McHenry CS. 2002. The HIV plus-strand transfer reaction: determination of replication-competent intermediates and identification of a novel lentiviral element, the primer over-extension sequence. J Mol Biol 315: 311-323. doi:10.1006/jmbi.2001.5205

Nishikura K, De Robertis EM. 1981. RNA processing in microinjected Xenopus oocytes. Sequential addition of base modifications in the spliced transfer RNA. J Mol Biol 145: 405-420. doi:10.1016/00222836(81)90212-6

Nordlund ME, Johansson JO, von Pawel-Rammingen U, Byström AS. 2000. Identification of the TRM2 gene encoding the tRNA $\left(m^{5} U_{54}\right)$ methyltransferase of Saccharomyces cerevisiae. RNA 6: 844-860. doi:10.1017/S1355838200992422

Nurse K, Wrzesinski J, Bakin A, Lane BG, Ofengand J. 1995. Purification, cloning, and properties of the tRNA $\Psi 55$ synthase from Escherichia coli. RNA 1: 102-112.

Ny T, Björk GR. 1980. Cloning and restriction mapping of the trmA gene coding for transfer ribonucleic acid (5-methyluridine)methyltransferase in Escherichia coli K-12. J Bacteriol 142: 371379.

Raba M, Limburg K, Burghagen M, Katze JR, Simsek M, Heckman JE, Rajbhandary UL, Gross HJ. 1979. Nucleotide sequence of three isoaccepting lysine tRNAs from rabbit liver and SV40-transformed mouse fibroblasts. Eur J Biochem 97: 305-318. doi:10.1111/ j.1432-1033.1979.tb13115.x

Renda MJ, Rosenblatt JD, Klimatcheva E, Demeter LM, Bambara RA, Planelles V. 2001. Mutation of the methylated tRNA ${ }^{\text {Lys }}{ }_{3}$ residue A58 disrupts reverse transcription and inhibits replication of human immunodeficiency virus type 1. J Virol 75: 9671-9678. doi:10.1128/JVI.75.20.9671-9678.2001

Rintala-Dempsey AC, Kothe U. 2017. Eukaryotic stand-alone pseudouridine synthases - RNA modifying enzymes and emerging regulators of gene expression? RNA Biol 14: 1185-1196. doi: 10.1080/15476286.2016.1276150

Roovers M, Hale C, Tricot C, Terns MP, Terns RM, Grosjean H, Droogmans L. 2006. Formation of the conserved pseudouridine at position 55 in archaeal tRNA. Nucleic Acids Res 34: 42934301. doi:10.1093/nar/gkl530

Safra M, Nir R, Farouq D, Slutzkin IV, Schwartz S. 2017a. TRUB1 is the predominant pseudouridine synthase acting on mammalian mRNA via a predictable and conserved code. Genome Res 27: 393-406. doi:10.1101/gr.207613.116

Safra M, Sas-Chen A, Nir R, Winkler R, Nachshon A, Bar-Yaacov D, Erlacher M, Rossmanith W, Stern-Ginossar N, Schwartz S. 2017b. The $\mathrm{m}^{1} \mathrm{~A}$ landscape on cytosolic and mitochondrial mRNA at single-base resolution. Nature 551: 251-255.

Schwartz S, Bernstein DA, Mumbach MR, Jovanovic M, Herbst RH, León-Ricardo BX, Engreitz JM, Guttman M, Satija R, Lander ES, et al. 2014. Transcriptome-wide mapping reveals widespread dynamic-regulated pseudouridylation of ncRNA and mRNA. Cell 159: 148-162. doi:10.1016/j.cell.2014.08.028

Suzuki T, Suzuki T. 2014. A complete landscape of post-transcriptional modifications in mammalian mitochondrial tRNAs. Nucleic Acids Res 42: 7346-7357. doi:10.1093/nar/gku390

Urbonavicius J, Auxilien S, Walbott H, Trachana K, GolinelliPimpaneau B, Brochier-Armanet C, Grosjean H. 2008. Acquisition of a bacterial RumA-type tRNA(uracil-54, C5)-methyltransferase by 
Archaea through an ancient horizontal gene transfer. Mol Microbiol 67: 323-335. doi:10.1111/j.1365-2958.2007.06047.x

van Weringh A, Ragonnet-Cronin M, Pranckeviciene E, PavonEternod M, Kleiman L, Xia X. 2011. HIV-1 modulates the tRNA pool to improve translation efficiency. Mol Biol Evol 28: 18271834. doi:10.1093/molbev/msr005

Watanabe Y, Gray MW. 2000. Evolutionary appearance of genes encoding proteins associated with box H/ACA snoRNAs: cbf5p in Euglena gracilis, an early diverging eukaryote, and candidate
Gar1p and Nop10p homologs in archaebacteria. Nucleic Acids Res 28: 2342-2352. doi:10.1093/nar/28.12.2342

Yang JA, Tai LW, Agris PF, Gehrke CW, Wong TW. 1983. The nucleotide sequence of a major glutamine tRNA from rat liver. Nucleic Acids Res 11: 1991-1996. doi:10.1093/nar/11.7.1991

Zucchini C, Strippoli P, Biolchi A, Solmi R, Lenzi L, D'Addabbo P, Carinci P, Valvassori L. 2003. The human TruB family of pseudouridine synthase genes, including the Dyskeratosis Congenita 1 gene and the novel member TRUB1. Int J Mol Med 11: 697-704. 

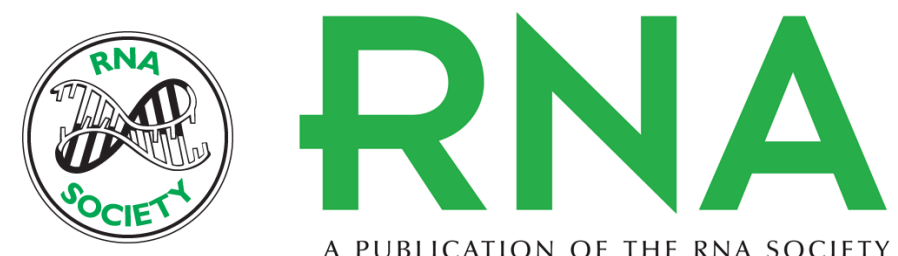

A PUBLICATION OF THE RNA SOCIETY

\section{The human ortholog of archaeal Pus10 produces pseudouridine 54 in select tRNAs where its recognition sequence contains a modified residue}

Manisha Deogharia, Shaoni Mukhopadhyay, Archi Joardar, et al.

RNA 2019 25: 336-351 originally published online December 7, 2018 Access the most recent version at doi:10.1261/rna.068114.118

Supplemental Material

References

Creative Commons License

Email Alerting Service
http://rnajournal.cshlp.org/content/suppl/2018/12/07/rna.068114.118.DC1

This article cites 59 articles, 20 of which can be accessed free at: http://rnajournal.cshlp.org/content/25/3/336.full.html\#ref-list-1

This article is distributed exclusively by the RNA Society for the first 12 months after the full-issue publication date (see http://rnajournal.cshlp.org/site/misc/terms.xhtml). After 12 months, it is available under a Creative Commons License (Attribution-NonCommercial 4.0 International), as described at http://creativecommons.org/licenses/by-nc/4.0/.

Receive free email alerts when new articles cite this article - sign up in the box at the top right corner of the article or click here.

\section{|||||||| Providing Precise Solutions for} your research.

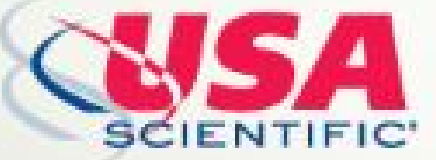

To subscribe to RNA go to:

http://rnajournal.cshlp.org/subscriptions

(C) 2019 Deogharia et al.; Published by Cold Spring Harbor Laboratory Press for the RNA Society 